\title{
How Proponents and Opponents Influence Achievement Motivation: The Role of the Anticipated Emotions of Other People
}

\author{
Bilson Simamorat \\ ${ }^{a^{*} K w i k ~ K i a n ~ G i e ~ S c h o o l ~ o f ~ B u s i n e s s ~ a n d ~ I n f o r m a t i o n ~ T e c h n o l o g y, ~ I n d o n e s i a ~}$
}

\begin{abstract}
There are countless studies about the influence of other people's emotions on individuals' behavior. However, the influence of proponents' and opponents' future emotions on achievement motivation remains unclear. This study aims to fill this gap. Therefore, departing from the emotional intelligence theory, the author materializes the anticipated emotions of other people concept and tests it using a static group experimental design with success and failure scenarios, involving 203 participants chosen judgmentally. When reminded of the proponents' joyfulness caused by their success, the Mann-Whitney $U$ test with normal approximation, supported by the Monte Carlo estimation, shows that the mastery-avoidance, performance-approach, and performance-avoidance goals of the experimental group are enhanced. Whereas, when reminded that they would be envied and make the opponents feel distressed, the performance-approach goals are improved. In the failure scenario, when the participants were directed to the proponents' distress, as a response to their failure, the four components of the achievement goals are increased: mastery-approach, mastery-avoidance, performance-approach, and performance-avoidance. However, the opponents' joyfulness, anticipated as a malicious schadenfreude to the participants' failure, is only successful in stimulating the performance-avoidance goals. A Bayesian estimate with 5,000 times bootstrapping reveals that self-efficacy mediates the influence of the proponents' anticipated joyfulness on the mastery-approach fully, and on the performance-approach goals in a complementary way. Complementary mediation is also apparent in the impact of the proponents' distress on the mastery-approach and mastery-avoidance goals. Above all, love for the proponents is more potent than hatred from social environments for increasing the achievement motivation. Further research is encouraged to replicate this study with different social behavior.
\end{abstract}

Keywords: anticipated emotions, social envy, schadenfreude, self-efficacy, achievement motivation.

JEL classification: M31 


\section{Introduction}

Marketers are deeply attracted to the concept of emotion (Bagozzi, Belanche, Casalo, and Flavian 2016). They are usually concerned with how emotions shape behavior or how behavior creates emotions (Tamir and Bigman 2018). Regarding how emotions shape behavior, marketers commonly presume that people can predict the emotional consequences of their success or failure to achieve goals. As the decision-makers, they can anticipate the consequences of their behavioral options, including their affective reactions to those consequences (Bagozzi et al., 2016; Volz and Hertwig 2016). This anticipation energizes their current efforts to achieve success or avoid failure in the future (Volz and Hertwig 2016; Baumgartner, Pieters, and Bagozzi 2007).

The extant literature has also discussed how significant others or prominent persons in one's life, such as family, friends, relatives, and teacher (e.g., Sun 2019; Passafaro, Livi, and Kosic 2019) and social competitors (e.g., Wang, Lilienfeld, and Philippe 2019; van de Ven and Zeelenberg 2020) influence one's behavior. More specifically, researchers (e.g., Fiori and Vesely-Maillefer 2018; Tamir and Bigman 2018; Israelashvili, Sauter, and Fischer, 2019) have acknowledged the individuals' efficacy in detecting other people's emotions, and then employing the proper behavior to adapt to them. Social envy and schadenfreude theories (e.g., Wang, Lilienfeld, and Philippe 2019; van de Ven and Zeelenberg 2020) state that people could predict social schadenfreude for their failure and be envious of their success. With this knowledge, they can use the proper behavior, if necessary, to be envied or avoid being viewed as a loser.

The studies about future emotions have also been flourishing and have given birth to various concepts, such as anticipated emotions (Bagozzi et al., 2016), anticipated pride and guilt (Grant and Wrzesniewski 2010; van der Schalk, Kuppens, Bruder, and Manstead 2015; Schneider, Zaval, Weber, and Markowitz 2017), and anticipated regret (Zeelenberg 2020). Anticipated admiration, mostly caused by benign envy, can be utilized to market high prestige products. However, in those studies, the individuals' future emotions are still the topic of concern. The discourse about other people's future emotions is still rare and lacks empirical support, especially those that take a clear demarcation line between other people as social companions or as competitors. This fact is the background of this study.

Departed from the above background, first, the author conceptualized other people as proponents and opponents and their future emotions as proponents' and opponents' anticipated emotions. The author presumes that the proponents' anticipated emotions are generated by love, whereas the opponents' anticipated emotions are produced by, to some extent, hatred spread on one's social environment. For reasons of simplification, the proponents' anticipated emotions (PAE) are categorized as the proponents' anticipated joyfulness (PAJ) and the proponents' anticipated distress (PAD), and the opponents' anticipated emotions are represented by the opponents' anticipated joyfulness (OAJ) and the opponents' anticipated distress (OAD).

Second, the author follows the notion that the anticipated emotions strongly influence the motivation to succeed or to avoid failure. Using achievement motivation to cover Bagozzi et al., (2016) success and failure scenario, as the concepts under investigation, the research problem is: What is the influence of other people's anticipated 
emotions on individuals' current achievement motivation? Subsequently, following the above "other people" categorization, the research questions are: (1) How does the proponents' joyfulness and distress, anticipated as the reactions to individual success and failure, influence the achievement motivation? (2) How do envy and schadenfreude, manifested in the opponent's distress and joyfulness about individuals' successes and failures, stimulate the achievement motivation?

Self-efficacy is the primary determinant of the achievement motivation (Schunk and Pajares 2009; Domenech-Betoret, Abellan-Rosello, and Gomez-Artiga 2017). It is interesting to verify, as the third research question: Is the influence of the proponents' and opponents' joyfulness and distress on the achievement motivation mediated by self-efficacy? To answer this question, the author should first answer a fundamental question: Do the two variables affect self-efficacy? Besides the above questions, this study also intends to verify: Which is the strongest one for influencing achievement goals, proponents' anticipated joyfulness, proponents' anticipated distress, opponents' anticipated joyfulness, or opponents' anticipated distress? In short, is the love of the proponents stronger than the hatred from the social environment in those functions?

As a theory of personality, the self-determination theory (Ryan and Deci 2017) can explain how proponents' anticipated joyfulness and distress influence the achievement motivation. In short, when extrinsic motivation, as manifested in those future emotions, has been introjected into one's regulations, it becomes intrinsically activated. It is also apparent that self-esteem, which functions as the main factor in schadenfreude and so- cial envy (van de Ven and Zeelenberg 2020; Brambilla and Riva 2017), can explain why people are eager to be envied or avoid being viewed as a loser. However, the discourse is still only at the theoretical reasoning stage, and lacks empirical support. Therefore, the answers to the above questions could be considered the original contributions of this study.

In an interconnected society, how others think and feel strongly influences individuals' behavior (Moussaid, Kammer, Analytis, and Neth 2013). For practical reasons, in addition to its scientific contributions, the concept under investigation is essential. In such a context, this study's results can be useful for people who may be concerned about increasing achievement motivation, promoting positive behavior and reducing negative behavior more effectively, by reminding the targets about the impact of their behavior and achievements on other's emotions.

\section{Literature Review}

\section{Anticipated Emotions of Others}

In the theory of future-oriented thinking (FOT), Eskritt, Doucette, and Robitaille (2014) stated that individuals could anticipate the potential consequences of their actions. Anticipation is a concept about how individuals await, not just predict the consequences of an event that are expected to occur shortly or in the long term, and prepare their-selves to deal with it, generated primarily by cognitive skills (Bozinovski and Bozinovska 2003) It often deals with the future consequences of behavior regarding a person's self-image and emotions (Eskritt, Doucette, and Robitaille 2014). The more experienced the individual is, the more accurate the anticipation is (Bozinovski and Bozinovska 2003). 
Besides the experienced emotions, marketing researchers pay a lot of attention to future emotions (Passafaro, Livi, and Kosic 2019; Tamir and Bigman 2018). Individuals can anticipate their own emotions, created by their success or failure to achieve their goals (Baumgarner et al., 2007; Bagozzi et al., 2016). Such emotions are called anticipated emotions (Baumgarner et al., 2007; Bagozzi et al., 2016). They can also anticipate the emotions of people they love (proponents) or people they are in social competition with (opponents) (Table 1). family), especially for Asian students (Chen, Wang, Wei, Fwu, and Hwang 2009; Liem and Nie 2008), including their Asian American counterparts (Kim et al., 2017). Hence, achieving the set goal is beneficial not only to the individual but also to the significant others around them, especially if they see the achievement as a gift (Simamora 2016). Consequently, people may pursue personal goals (i.e., goals constructed by individuals' autonomous interests) and vertical goals (i.e., goals related to the family's well-being) (Chen et al., 2009; Liem and Nie 2008). People can

Table 1. The Anticipated Emotions of Others'

\begin{tabular}{|c|c|c|}
\hline \multirow{2}{*}{ Others } & \multicolumn{2}{|c|}{ Individual's Task Accomplishment in the Future } \\
\hline & Success & Failure \\
\hline \multirow[b]{2}{*}{ Proponents } & Positive proponents' anticipated emotions: & Negative proponents' anticipated emotions: \\
\hline & $\begin{array}{l}\text { Liking, happy, satisfied, like, pleased, inspired, } \\
\text { pleasure, pride, surprise, thankful, joyfulness, win, } \\
\text { released, confident }\end{array}$ & $\begin{array}{l}\text { Anger, regret, sad, disappointed, bur- } \\
\text { dened, despicable, ashamed, cynical, frus- } \\
\text { tration sadness, hopeless, dislike, anxiety }\end{array}$ \\
\hline \multirow{2}{*}{ Opponents } & Negative anticipated emotions of opponents: & Positive anticipated emotions of opponents: \\
\hline & $\begin{array}{l}\text { Dislike, unhappy, uncomfortable scornful, jittery, } \\
\text { cynical, sad, despicable }\end{array}$ & $\begin{array}{l}\text { Happy, surprise, joyfulness, released, satis- } \\
\text { fied, win, joyfulness excited, pleased, like }\end{array}$ \\
\hline
\end{tabular}

Source: Adapted from Simamora, B., 2016. Achievement as gift and prestige: Formulating anticipated emotions of others as new determinant of consumers' motivation. ASEAN Marketing Journal, 8 (1), 29-53.

\section{Proponents' Anticipated Emotions}

Proponents are the people an individual has a good relationship with or those who love an individual and expect good things to happen to him/her (Simamora 2016). They could be family, friends, or teachers. An individual can use his/her own anticipated emotions (Baumgartner, Pieters, and Bagozzi 2007; Bagozzi et al., 2016) or their proponents' anticipated emotions (Table 1) as goals; toward which the individual's current efforts are energized.

The effort to meet goals can be an obligation owed to prominent persons (such as regulate their behavior to avoid failure or to succeed, to satisfy their proponents' anticipated emotions.

\section{Opponents' Anticipated Emotions}

Opponents are people with whom an individual is involved in social competition, or open or silent hostilities. In Indonesia, there is a cultural trait called sirik that represent schadenfreude and social envy well. Schadenfreude is an individual's or group's joy when observing other people's misfortunes (Wang, Lilienfeld and Philippe 2019). It typically happens in competitive circum- 
stances (Wang, Lilienfeld, and Philippe 2019), correlates with self-esteem (van de Ven and Zeelenberg 2020), and occurs at the individual and group levels (Brambilla and Riva 2017).

There are four conditions when schadenfreude commonly occurs. First, when the observers benefit from other people's misfortunes. When a rival's failure opens an opportunity or results in a gain for an observer, schadenfreude tends to occur. Second, schadenfreude occurs when observers see that other people deserve their misfortune because of their hypocrisy or a sense of injustice over a person who suffers from the misfortune (Wang, Lilienfeld and Philippe 2019). In this way, the observers view the misfortune as a logical answer to that hypocrisy and injustice. The third condition is if the misfortune is experienced by people who are envied or those who occupy a superior position. Self-esteem would decrease when such people suffer from misfortunes (van de Ven and Zeelenberg 2020). At the same time, the observers will feel an increase in their own self-esteem. Therefore, the envied person's misfortune will bring both parties' self-esteem into better balance. The fourth condition, schadenfreude, occurs because of the observer's resentment of the person suffering the misfortune (Leahy 2020).

Social envy appears when an individual witnesses that the envied person or group has a valuable object that produces feelings of inferiority and resentment. It stems from an upward comparison, in which the individual (the envier) compares himself or herself to a superior person (the envied) in terms of the ownership of the envied object (van de Ven and, Zeelenberg 2020). Envy is generated not by the fact that the rival does well, but does better than the envious person.
A gain by others is felt as a lost to oneself. Such an evaluation generates a collection of emotions that may occur during the episode, which may include feelings of inferiority, hatred of the situation, and bad feelings toward the envied person (Leahy 2020).

\section{Achievement Motivation}

Skill-related factors or chance-related factors can produce a behavioral outcome. With skill-related factors, results are determined by one's ability. The higher the ability is, the greater the expectancy is. Prior success or failure will influence the perception of ability. In chance-related situations, such as the flip of a coin, expectancy remains the same regardless of whether the subject was successful or failed in a prior experience (Nichols 1984; Ames 1992).

Achievement motivation is a driving force within individuals by which emotions, competencies, cognition, and behavior are energized and directed to achieve achievement goals (Rosas 2015). It is relevant to behavior in which outcomes are produced by skill or effort-related factors. Achievement goals are a competence-based purpose that drive and guide achievement behavior (Nichol, 1984; Gegenfurtner and Hagenauer 2013). Achievement goal orientation is a relatively stable tendency toward which an individual is more attracted (Gegenfurtner and Hagenauer 2013; Elliot and McGregor 2001). Achievement goals become the icon of achievement motivation (Ratsameemonthon 2015; Rosas 2015). In this study, both are used interchangeably.

Initially, for the achievement motivation concept, the scientists' only concern is with the demonstration of high levels of skill and producing excellent performances. It is viewed as relevant only for highly competent 
Gadjah Mada International Journal of Business - January-April, Vol. 23, No. 1, 2021

people. Nichol (1984) accordingly said that with achievement motivation, individuals aim to demonstrate their high achievement and show off their ability. Further, Ames (1992) stated that achievement goals consist of a mastery goal that was purposed to develop capability, and performance goals that reflect a willingness to demonstrate ability.

In its development, in addition to the above approach, scientists add the avoidance valence of achievement motivation. Elliot and Harackiewicz (1991) introduced the third goal called performance-avoidance goals and baptized their trichotomous model. It represents the motivation to increase the skill or competence required to master a task (mastery goals), a willingness to beat others, and show off one's capability (performance-approach goals) and avoid being beaten or viewed as incompetent by one's peers (performance-avoidance goals). The first two goals are presumed to be owned by high-efficacy people, and the third goal belongs to low self-efficacy people.

In 2001, Elliot and McGregor (2001) added a fourth dimension, called mastery-avoidance, which represents individuals' willingness to avoid failure when mastering a skill or competence. Their so-called $2 \times 2$ model has two valences (approach and avoidance) and two focuses (mastery and performance) and specified its achievement goals into four elements: mastery-approach, mastery-avoidance, performance-approach, and performance-avoidance. Countless studies have confirmed the validity of this model (Ratsameemonthon 2015; Rosas 2015).

\section{Self-Efficacy}

Self-efficacy is an individual's belief that they have the competence or capabili- ty to perform a task and reach the set goals successfully. Self-efficacy determines the individuals' confidence to face a challenge or perform a task. People with high self-efficacy are more receptive to and optimistic about a difficult task, and they see it as a challenge instead of an obstacle or threat. Conversely, low-efficacy people are generally less optimistic and tend to avoid difficult tasks or complain because they see them as obstacles or threats (Schunk and Pajares 2009).

Sometimes, perceived-difficulty is used as a substitute for self-efficacy. Low self-efficacy people tend to have high perceived difficulty. High self-efficacy people tend to have low perceived difficulty when performing tasks, especially tasks where the outcomes are certain or predictable (Huang 2016; Schunk and Pajares 2009).

\section{The Influence of Proponents' Antici- pated Emotions on Achievement Moti-} vation

The author used the cognitive balance theory to formulate the influence of proponents' anticipated emotions on achievement motivation. This theory consists of a triadic relationship among proponents, individuals, and attitudinal objects (Belaza et al., 2017; Munroe 2019). It asserts that people tend to maintain a cognitive and emotional balance with the people they have a close relationship with. Cognitive and emotional congruence between individuals and proponents strengthens the balance. When cognitive and emotional incongruence occurs, individuals would adapt their or the other people's behavior to regain a congruent attitude. Such changes are required because individuals will experience psychological discomfort when they find that their own and their proponents' cognition and emotions are incongruent. 
In this study, the proponents' anticipated emotions, individual emotions, and the success or failure to achieve the goals are all involved in a triadic relationship. Proponents enjoy individuals' successes and dislike their failures. Therefore, individuals' successes will strengthen the emotional balance by pursuing success and avoiding failure, which generates emotional incongruence. Consequently, individuals will be motivated to generate the proponents' happiness and avoid their distress through achieving the set goals, as stated in the following hypotheses:

H1: The stronger the proponents' anticipated joyfulness is; in response to the individuals' successes, the higher are the (a) mastery-approach, (b) mastery-avoidance, (c) performance-approach, and (d) performance-avoidance goals.

H2: The stronger the proponents' anticipated distress is; in response to the individuals' failure, the higher are the (a) mastery-approach, (b) mastery-avoidance, (c) performance-approach, and (d) performance-avoidance goals.

\section{The Influence of Opponents' Antici- pated Emotions on Achievement Moti- vation}

People can anticipate their opponents' joyfulness (such as pleasure, happiness, release, satisfaction, and excitement) about their own misfortune or loss in a social competition. They can also anticipate their opponents' distress (such as dislike, unhappiness, disomfort, scorn, jittery, and cynical) about their own lucky or high position. Those future-oriented emotions are called opponents' anticipated emotions.

These emotions can be traced to the emotional intelligence concept (Fiori and Ve-
sely-Maillefer 2018). It specified that an individual could predict other people's emotions and then manage their behavior to generate feelings or prevent them from experiencing certain emotions. The theory highlights that people could develop reasons to perceive, assess, and generate feelings. With such capabilities, individuals can anticipate their opponents' emotional reactions to their future success or failure.

Which opponents' emotions can an individual anticipate? It depends on the individual's position in a social competition. Envied people should have a significant opportunity to win the competition or beat their opponents, and experience the feeling of winning. People in this position have the advantage of superiority (Van de Ven and Zeelenberg 2020; Wang, Lilienfeld, and Philippe 2019). They may strive to beat their opponents, to make them feel distressed. On the other hand, people who have a high risk of failure know that they can be a target for their opponents' schadenfreude and try to get rid of it by avoiding failure.

Beating the enviers (approach motivation) and avoiding becoming the target of schadenfreude (avoiding motivation) can be the goals. The first goal, owned by people with high self-efficacy, occurs in a downward social contrast. The second goal, owned by people with low self-efficacy, is produced by an upward social comparison. People in the average position can be involved in upward and downward social comparisons simultaneously. Consequently, in the context of a social relationship, people can be sensitive to their opponents' joyfulness and distress, and driven by approach, avoidance, or approach and avoidance motivations at the same time.

The aspect of demonstration places achievement motivation as one of the envy 
objects (van de Ven and Zeelenberg 2020). The general premise is that opponents' anticipated emotions positively influence achievement motivation. Precisely, in a social competition where the sirik trait works, a willingness to avoid becoming the target of schadenfreude, and a desire to be envied are manifested in the opponents' anticipated joyfulness and distress, then those anticipations stimulate the achievement motivation.

As stated before, people are aware of, and anticipate, their opponents' enjoyment when they fail to reach an achievement they deserve, or fall below the opponents' level. Being a loser is an uncomfortable position (Leahy 2020; van de Ven and Zeelenberg 2020; Wang, Lilienfeld, and Philippe 2019). People will regulate their behavior to avoid failure and prevent finding themselves in the position of being the object of their opponents' feelings of pleasure. The author believes that the stronger the opponents' anticipated joyfulness is, the higher the individuals' motivation to avoid failure is, as formalized in the following hypotheses:

H3: The stronger the opponents' joyfulness is, anticipated as schadenfreude emotions about the individuals' failure, the higher the performance-avoidance goals are.

People are also aware of their opponents' distress when they succeed in achieving their goal or climbing above the opponents' level. The willingness to envy their opponents, or create feelings of distress in them, can drive the motivation to succeed or win a competition, as stated as follows:

H4: The stronger the opponents' distress is, anticipated as social envy of the individuals' success, the higher the the performance-approach goals are.

\section{Mediating Effect of Self-Efficacy}

The influence of emotions that are experienced toward other people about self-efficacy can be found in studies by Buonomo, Piorilli, and Benevene (2017). Specifically, they found that teachers' positive emotions toward students increased the teachers' self-efficacy. However, the influence of other people's anticipated emotions on self-efficacy is still absent from recent studies. Fortunately, Bosone and Martinez's (2017) work can be used as a starting point. They said that when framed with future gains, people show no increase in creativity efficacy. On the other hand, when reminded about losses, a rise in their creativity efficacy can be expected.

In this study, the proponents' anticipated distress and the opponents' anticipated joyfulness are viewed as congruent with expected losses. Based on Buonomo, Piorilli, and Benevene (2017), the author expects that, when aware of these anticipated emotions, individuals will, as a form of self-protection from anticipated guilt, increase their self-efficacy as Roger's self-protection motivation theory (Maddux and Roger 1983, Westcott et al., 2017) specified.

Proponents' anticipated joyfulness and distress are viewed as having the same tone with expected gains. Therefore, based on Buonomo, Piorilli, and Benevene (2017), the author expects that people will show no increase in their self-efficacy when aware of them.

Countless studies have confirmed the effect of self-efficacy on achievement motivation (Schunk and Pajares 2009; Domenech-Betoret, Abellan-Rosello, Gomez-Artiga 2017). As stated before, when treated as anticipated gains and losses, the proponents' and opponents' anticipated emotions influ- 
ence self-efficacy. Therefore, other people's anticipated emotions can also be expected to influence the achievement motivation, as specified in the following hypotheses:

H5: Self-efficacy has no mediating effect on the influence of proponents' anticipated joyfulness on the (a) mastery-approach, (b) mastery-avoidance, (c) performance-approach, and (d) performance-avoidance goals.

H6: Self-efficacy mediates the influence of proponents' anticipated distress on the (a) mastery-approach, (b) mastery-avoidance, (c) performance-approach, and (d) performance-avoidance goals.

H7: Self-efficacy mediates the influence of opponents' anticipated joyfulness on the performance-avoidance goals.

H8: Self-efficacy has no mediating effect on the influence of opponents' anticipated distress on the performance-approach goals.

\section{Research Method}

\section{Review and Legitimation}

This study is part of a research program by the Kwik Kian Gie School of Business and Information Technology, a business school located in Jakarta, Indonesia. Initially, an open review was conducted by a research committee, organized by the Institute of Research and Community Service (in the Indonesian language: Lembaga Penelitian dan Pengembangan Masyarakat) to evaluate the study's technical and ethical feasibility. When found to be feasible, this study was given permission to proceed, formalized in an assignment letter numbered 147a.117/IBIKKG/
ST/111/2018, March 15, 2018. The decision would automatically be cancelled if the committee found any unethical practices in the study's execution.

\section{Research Site Selection}

The relevant assignment in this study was to find which positive outcomes are viewed as a gift to the proponents or have prestige value for an individual who completes the prestigious assignment well. A gift is something of value that one gives to someone else (Goodman and Lim 2018). Achievement in a university can fulfill those prerequisites as it influences significant others' well-being (Chen et al., 2009). It also has prestige value as enviers can envy it (van de Ven and Zeelenberg 2020).

For that reason, this study is conducted at a business college located in North Jakarta, in which the students commonly come from traditional families that have interdependent feelings and thoughts (Moussaid, Kammer, Analytis, and Neth 2013) and view their success and failure as a collective matter (Munroe 2019). Besides, the students commonly come from the middle social class, who are more likely to define their self-image with regard to their social status (Manstead 2018).

\section{Experiment Design}

This study utilized a static group design in which the participants' selection was not randomized, and the researcher placed no restrictions on the study's environment. This pre-experimental design is allowed for a homogenous population. However, to some extent, the researcher should ensure the participants' homogeneity and, as suggested by Malhotra (2020), use proper statistical tools. 
Gadjah Mada International Journal of Business - January-April, Vol. 23, No. 1, 2021

This study involved 203 students, enrolled in six classes of the Intermediate Financial Accounting course, who acted as the partic-

that those groups had the same average age $(\mathrm{F}=0.26$, sig. $=0.78)$ and $\mathrm{GPA}(\mathrm{F}=2.22$, sig. $=0.11)$ (Table 2).

Table 2. The Description of the Participants from the Accounting Department

\begin{tabular}{|c|c|c|c|c|c|c|}
\hline Properties & & $\begin{array}{r}\text { Control Group } \\
\text { (No Stimula- } \\
\text { tion) } \\
(\mathrm{N}=40)\end{array}$ & $\begin{array}{r}\text { Group } 1 \text { (Stim- } \\
\text { ulated with } \\
\text { Proponents' } \\
\text { Joyfulness) }(\mathrm{N} \\
=42)\end{array}$ & $\begin{array}{r}\text { Group } 3 \\
\text { (Stimulated with } \\
\text { Opponents' } \\
\text { Distress) } \\
(\mathrm{N}=28)\end{array}$ & $\begin{array}{r}\text { Total } \\
(\mathrm{N}=110)\end{array}$ & ANOVA \\
\hline \multirow[t]{2}{*}{ Age (years) } & Average & 19.45 & 19.46 & 19.34 & 19.41 & $F=0.26$ \\
\hline & S.dev & 0.49 & 0.67 & 0.49 & 0.65 & Sig. $=0.78$ \\
\hline \multirow[t]{3}{*}{ GPA } & Average & 3.31 & 3.44 & 3.27 & 3.35 & $F=2.22$ \\
\hline & S.Dev & 0.37 & 0.35 & 0.37 & 0.37 & Sig. $=0.11$ \\
\hline & Male & 20 & 9 & 11 & 40 & - \\
\hline \multirow{2}{*}{ Gender } & Female & 20 & 33 & 17 & 70 & - \\
\hline & $\begin{array}{l}\text { One-Sample } \\
\text { Binomial Test }\end{array}$ & Sig. $=1.00$ & Sig. $=0.00$ & Sig. $=0.35$ & - & - \\
\hline
\end{tabular}

ipants. Each class formed a separate group. They consisted of 110 students from the accounting department grouped into three classes, and 93 students from the management department enrolled in three classes.

The author intentionally separated students from the accounting and management departments, to control their academic majors' effect on the self-efficacy and achievement goals. Students from the accounting department are presumed to have higher self-efficacy and achievement goals than students from the management department, as the subject is their compulsory course. Students from the accounting department were involved in three groups: the control group (no treatment) and two experimental groups (Group 1: framed with positive proponents' anticipated emotions vs. Group 3: framed with opponents' joyfulness), in a between-groups design.

The experimental and control groups should have the same major, ages, and grade point average (GPA) to reduce bias selection. The research conducted an F-test to ensure
Students from the management department were involved in three groups in a quasi-experiment: one control group and two experimental groups (Group 2: framed with opponents' distress vs. Group 4: framed with proponents' distress), in a between-groups design. Those three groups had the same average age $(F=1.37$, sig. $=0.26)$ and GPA $(F$ $=1.29$, sig. $=0.28)$, as exhibited in Table 3.

The binomial test indicated that the proportion of males and females in Group 1 (sig. $=0.00$ ) was not the same (Table 2). The control group of management students also indicated the same result (Sig. $=0.02, \mathrm{Ta}$ ble 3). However, the different proportion of males and females was not expected to affect the self-efficacy and achievement goals since both segments were the same in terms of the two variables' mean. For accounting students, the analysis of the ANOVA results revealed that males and females had the same mastery-approach $(\mathrm{F}=0.14$, sig. $=0.71)$, mastery-avoidance $(F=1.00$, sig. $=0.32)$, performance-approach $(\mathrm{F}=2.48$, sig. $=0.12)$, and performance-avoidance $(\mathrm{F}=0.52$, sig. $=$ 
Table 3. The Description of the Participants from the Management Department

\begin{tabular}{|c|c|c|c|c|c|c|}
\hline Properties & & $\begin{array}{r}\text { Control Group } \\
\text { (No Stimula- } \\
\text { tion) } \\
(\mathrm{N}=33)\end{array}$ & $\begin{array}{r}\text { Group } 2 \text { (Stim- } \\
\text { ulated with } \\
\text { Opponents' } \\
\text { Joyfulness) (N } \\
=39)\end{array}$ & $\begin{array}{r}\text { Group } 4 \\
\text { (Stimulated with } \\
\text { Proponents' } \\
\text { Distress) } \\
(\mathrm{N}=21)\end{array}$ & $\begin{array}{r}\text { Total } \\
(\mathrm{N}=93)\end{array}$ & ANOVA \\
\hline \multirow[t]{2}{*}{ Age (years) } & Average & 19.49 & 19.24 & 19.78 & 19.45 & \multirow{2}{*}{$\begin{array}{c}F=1.37 \\
\text { Sig. }=0.26\end{array}$} \\
\hline & S.dev & 0.96 & 1.56 & 0.66 & 1.21 & \\
\hline \multirow[t]{3}{*}{ GPA } & Average & 3.12 & 2.97 & 3.18 & 3.11 & \multirow{2}{*}{$\begin{array}{c}F=1.29, \\
\text { Sig. }=0.28\end{array}$} \\
\hline & S.Dev & 0.08 & 0.41 & 0.50 & 0.47 & \\
\hline & Male & 24 & 15 & 12 & 51 & - \\
\hline \multirow{2}{*}{ Gender } & Female & 9 & 24 & 10 & 42 & - \\
\hline & $\begin{array}{l}\text { One-Sample } \\
\text { Binomial Test }\end{array}$ & Sig. $=0.02$ & Sig. $=0.20$ & Sig. $=0.52$ & - & - \\
\hline
\end{tabular}

0.47) goals as well as self-efficacy $(F=0.57$, sig. $=0.45)$. The same test with the management department's groups also indicated the same result for mastery-approach $(\mathrm{F}=1.93$, sig. $=0.18)$, mastery-avoidance $(F=0.61$, sig. $=0.44)$, performance-approach $(\mathrm{F}=0.58$, sig. $=0.45)$, and performance-avoidance $(\mathrm{F}=$ 0.00 , sig. $=0.98)$ goals, as well as self-efficacy $(\mathrm{F}=1.30$, sig. $=0.26)$.

\section{Procedure}

The study proceded as follows: It was conducted in six accounting classes. Each class was treated as a separated study group. Twenty minutes before a chosen session ended, the author made a dramatic speech, as part of the experiment, to each experimental group. To Group 1, the speech's topic was, "How happy the proponents would be if you were successful." Group 2 got the topic of, "How happy the opponents are when you fail." Group 3 had, "How miserable the opponents are when you are successful." Group 4's topic was, "How sad the proponents will be if you fail." No speech was made to the control groups.

After the speech, the author asked permission to share the questionnaire's website link via Whatapps, through which the partic- ipants can open and read more about the visualized treatment and fill-in the online questionnaire. It was emphasized that participation was voluntary and anonymous. The participants could fill-in the questionnaire anytime after the class session, before the day ended, or leave it blank if they thought it was unnecessary.

At the end of the online questionnaire, the author generated a rectangular empty space in the computer screen, where the participants could guess and write the study's purpose. Analysis of the replies showed that all the answers were very diferent to the study's actual purpose, and therefore the treatment had no effect on the dependent variable.

\section{Experimentation}

Group 1 were framed with the statement: "If you are successful with your studies, people who love and care for you will feel happy, satisfied, pleased, inspired, proud, surprised, thankful, joyful, win and released and confident." In the questions sheet, the author dramatized this statement with a caricature of joy. Fourten statements about each item of the proponents' joyful- 
ness in Table 1 were displayed to emphasize the emotions experienced by the proponents, caused by the participants' success in their studies. For example, "The people that love and care for you will LIKE you if you are successful in your studies." Each item of the proponents' joyfulness was written in capital letters and highlighted with a bright color in the background. As mentioned before, the participants' responses to each statement were measured using a 7 -point Likert scale $(1=$ strongly disagree, $7=$ strongly agree).

Group 3 were reminded of the opponents' negative emotions if they are successful: "If you are successful in your studies, people who envy or hate you openly or silently will dislike you, and feel unhappy, uncomfortable, scornful, jittery, cynical, sad, and despicable about themselves. A caricature of a cynical face was embedded in the instrument to emphasize the statement. The statement was followed by eight statements associated with the opponents' distress, taken from Table 1. For example, "The people that envy or hate you openly or silently will DISLIKE you if you are successful in your studies. " Bright colors were used to highlight each emotion written in capital letters. The participants responded to each statement via a 7-point Likert scale (1 = strongly disagree, $7=$ strongly agree).

Group 2 were prepared by reminding them about how happy their opponents would be if they failed in their studies: "If you fail in your studies, people who envy or hate you openly or silently will feel satisfied, happy, joy, spirited, and released. The caricature of an evil face was added to the instrument to bring greater attention to the statement. The statement was followed by nine statements associated with the positive emotions of opponents depicted in Table 1. For example, "The people that envy or hate you openly or silently will feel HAPPY if you are failure in your studies." Each emotion in the statements was highlighted by a bright background color. Each statement's response was measured on a 7-point Likert scale ( $1=$ strongly disagree, 7 = strongly agree).

Group 4 were framed with the proponents' anticipated emotions if they fail in their studies: "If you fail in your studies, people that love and care for you will hate you and feel anger, regret, sadness, disappointment, burdened, despicable, ashamed, cynical, frustrated, hopeless, dislike for you, and anxiety. A caricature of a sad face accompanied that statement in the instrument. Then, thirteen statements associated with each emotion were presented to focus greater attention on the proponents' anticipated emotions. For example, "The people that love or care for you will feel ANGER if you are not successful in your studies." Each emotion in the statements is typed in capital and highlighted with a bright background color to emphasize its presence. The participants responded to each statement using a 7 -point Likert scale (1 $=$ strongly disagree, $7=$ strongly agree).

Group 5 were positioned as the control group for the management student participants and Group 6 were for the accounting student participants. No experimentation was made with the control groups.

\section{Dependent Variables}

After experiencing the experimentation, the participants in the experimental groups filled-in the questionnaire about self-efficacy and achievement goals. As stated before, self-efficacy is an individuals' belief that they can accomplish tasks and reach goals (Schunk and Pajares 2009). Achievement goals are a competence-based purpose toward which achievement behavior is directed (Nichol 1984; Gegenfurtner and Hagenauer 2013). 
The Indonesian version of the self-efficacy instrument from Pintrich et al., (1991) was used to measure self-efficacy (Table 4). The questions were exhibited in the form of a statement. For example, "You believe that you can finish your studies in this college with a high GPA? (Item 1)." The responses were recorded using a 7-point Likert scale, ranging from strongly disagree (score $=1$ ) to strongly agree $($ score $=7)$.

The Indonesian version of Eliot and Murayama's (2008) tool, called AGQ-R (Achievement Goal Questionnaire-Revised), was used to measure the dependent variables. This tool consists of 12 questions that belong to four motivation categories, as specified in Table 5. The questions were also displayed in the form of statements, for example, "My aim is to completely master the material presented in this class (Item 1)."

The participants' responses were recorded using a 7-point Likert scale, ranging from strongly disagree $($ score $=1)$ to strongly agree $($ score $=7)$. The data were collected two weeks before the mid-semester test to avoid the test result's effect, if any, on the study's results.

\section{Result}

\section{Validity and reliability analysis}

As exhibited in Table 4, the items of self-efficacy exceeded all the indicators for internal validity (FL $>0.50$, AVE $>0.60, \mathrm{CR}$ $>0.70)$ specified by Hair, Black, Babin, and Anderson (2016). Therefore, all the items were valid because they described the same construct. Cronbach's alpha also indicated excellent reliability $\left(r_{11}>0.70\right)$ for the self-efficacy instruments. The achievement goals' measurements were also valid as they satisfied all of the criteria for internal validity (FL $>0.50$, AVE $>0.60, \mathrm{CR}>0.70)$. The instruments were also reliable $\left(\mathrm{r}_{11}>0.70\right)$ (Table 5).

Table 4. Validity and Reliability Test of Self-Efficacy

\begin{tabular}{|c|c|c|c|c|c|}
\hline Items & Instruments & $\begin{array}{l}\text { Factor } \\
\text { Loading } \\
\text { (FL) }\end{array}$ & $\begin{array}{l}\text { Average } \\
\text { Variance } \\
\text { Extracted } \\
\text { (AVE) }\end{array}$ & $\begin{array}{l}\text { Construct } \\
\text { Reliability } \\
\text { (CR) }\end{array}$ & $\begin{array}{l}\text { Cronbach } \\
\text { Alpha }\end{array}$ \\
\hline 1 & $\begin{array}{l}\text { You believe that you can finish your studies in this } \\
\text { college with a high GPA }\end{array}$ & 0.67 & & & \\
\hline 2 & $\begin{array}{l}\text { You believe that you can master the lecture material } \\
\text { in this college, even the most difficult ones }\end{array}$ & 0.73 & & & \\
\hline 3 & $\begin{array}{l}\text { You believe that you can master the basic concept of } \\
\text { every course in this college }\end{array}$ & 0.77 & & & \\
\hline 4 & $\begin{array}{l}\text { You believe that you can master the most difficult } \\
\text { assignment given by lecturers in this college }\end{array}$ & 0.68 & 0.58 & 0.85 & 0.90 \\
\hline 5 & $\begin{array}{l}\text { You expect that you can pass every assignment and } \\
\text { test in this college }\end{array}$ & 0.85 & & & \\
\hline 6 & $\begin{array}{l}\text { You expect that you can be the best in every course in } \\
\text { this college }\end{array}$ & 0.86 & & & \\
\hline 7 & $\begin{array}{l}\text { You expect that you can finish your studies in this } \\
\text { college with the best results }\end{array}$ & 0.76 & & & \\
\hline
\end{tabular}


Gadjah Mada International Journal of Business - January-April, Vol. 23, No. 1, 2021

Table 5. Validity and Reliability of Achievement Goals

\begin{tabular}{lllll}
\hline & & Factor & Average & Construct \\
Items & Instruments & Loading & Variance & Extracted \\
& & (FL) & $\begin{array}{l}\text { Reliability } \\
\text { (AVE) }\end{array}$ & (CR)
\end{tabular}

Mastery Approach

1 My aim is to master the material presented in this class completely

3 I am striving to understand the content of this

course as thoroughly as possible

$0.62 \quad 0.75$

0.82

$7 \quad$ My goal is to learn as much as possible

0.77

Mastery Avoidance

5 My aim is to avoid learning less than I possibly could

My goal is to avoid learning less than it is possible to learn

0.74

0.58

0.71

0.75

11 I am striving to avoid an incomplete understanding of the course material

Performance Approach

2 I am striving to do well compared to the other students

4 My aim is to perform relatively well relative to the other students

8

My goal is to perform better than the other students

Performance Avoidance

6 My goal is to avoid performing poorly compared to the other students

10 I am striving to avoid performing worse than the other students

12 My aim is to avoid doing worse than the other students

0.76

Source: Eliot, A.J., and K. Nakamura, 2008. On the measurement of achievement goals: Critique, Illustration, and Application. Journal of Educational Psychology, 100 (3), 613-628.

Structural equation modeling with LISREL was utilized for the validity test and showed that the measurement model of self-efficacy and achievement goals had a bad but acceptable fit according to the root mean square error of approximation (RMSEA), which was equal to 0.092. However, the model was a good fit, as indicated by the Comparative Fit Index $=0.95$, the Normed Fit Index $(\mathrm{NFI})=0.92$, the Non-Normed Fit Index $(\mathrm{NNFI})=0.94$, the Incremental
Fit Index $(\mathrm{IFI})=0.95$, and the Relative Fit Index $(\mathrm{RFI})=0.91$.

\section{Main Effect}

\section{Preview}

As a pre-experimental design, this study used a non-parametric statistical method, namely the Mann-Whitney $U$ test, to test 
the main effect. This test requires that the dependent variables use at least an ordinal scale, the independent variable consists of at least two categories, and the measurement in each group is conducted independently. This test can adapt to a small sample size, and the non-normal and non-identical distribution of the two groups of data being compared.

To conduct this test, we needed to rank the cases in the two groups being compared (i.e., the experimentation and control group) simultaneously, then calculate the $U$ statistic for the $i$-th experimental group and control group using the following equation:

$$
U_{e i}=R_{e i}-\frac{n_{e i}\left(n_{e i}+1\right)}{2}
$$

The $U_{e i}$ is the Mann-Whitney statistic value. The $R_{e i}$ denotes the number of rankings of the $i$-th case noted as being higher than those of the control group. The $n_{e i}$ states the number of participants in the $i$-th group experiment. For the control group, the equation was:

$$
U_{c}=R c-\frac{n_{c}\left(n_{c}+1\right)}{2}
$$

The $U_{c}$ is the Mann-Whitney statistic value for the control group; while $R_{e i}$ is the frequency with which the control group's case is ranked higher than that of the experimental group. Lastly, the $n_{c}$ denotes the number of participants in the control group.

Under the manual protocol, we should use the small $U$ to find the corresponding p-value. However, because the sample's size was large (20 or higher), this study made a normal approximation to get the $z$-value, $u$ sing the following equation:

$$
z=\frac{U-m_{u}}{\sigma u}
$$

$U$ is the smaller value from two values generated by equations 1 and 2 , and the $m_{u}$ and $\sigma$ are the mean and standard deviation of $U$ denoted in equations 4 and 5:

$$
\begin{gathered}
m_{u}=\frac{n_{e i} n_{c}}{2} \\
\sigma_{u}=\sqrt{\frac{n_{e i} n_{c}\left(n_{e i} n_{c}+1\right)}{12}}
\end{gathered}
$$

If we find two or more participants share the rank $i$ (ties ranks), we should correct the $\sigma_{u}$ using Equation 6:

$\sigma_{\text {corr }}=\sqrt{\frac{n_{e i} n_{c}}{12}\left((n+1)-\sum_{i=1}^{k} \frac{t_{i}^{3}-t_{i}}{n(n-1)}\right)}(6)$

where $k$ is the number of distinct ranks, $t$ is the number of participants that share the rank $i$, and $n=n_{e i}+n_{i}$. This test was used to test for the null $H_{0}: P\left(y_{i e_{n}}>y_{i c}\right)=0.5$ or the probability of the dependent variable $i$ of the experimental group $m$ being higher than that of the control group, which was 0.5. The alternative hypothesis was $H_{o}: P\left(y_{i_{m}}>y_{i c}\right)>0.5$ or the probability of the dependent variable $i$ of the experimental group $m$ being higher than that of the control group, meaning it was higher than 0.5. The calculation of the $z$-value used the facility available in SPSS version 22 .

To interpret the $z$ value generated by the normal approximation, the author used an exact interpretation for the normal distribution's presumption. However, since the data's distribution were unknown, as a comparison, the author also applied the Monte Carlo estimation with 5,000 times bootstrapping, with a confidence level of $95 \%$. This approach needed no prior knowledge of the variables' distribution (Preacher and Hayes 2004; MacKinnon, Lockwood, and Williams 2004).

Testing H1: The stronger the proponents anticipated joyfulness is; in response to individuals' successes, the higher are the (a) mastery-approach, (b) mas- 
Gadjah Mada International Journal of Business - January-April, Vol. 23, No. 1, 2021

tery-avoidance, (c) performance-approach, and (d) performance-avoidance goals.

Using $\alpha=0.05$ as a maximum accepted error, the Mann-Whitney t-test revealed that experimentation using Group 1, with tery-avoidance $[\mathrm{t}=-3.534$, sig. $(1$-tailed $)=$ $0.000]$, performance-approach $[\mathrm{t}=-3.534$, sig. $(1$-tailed $)=0.000]$, and performance-avoidance goals $[\mathrm{t}=-1.740$, sig. $(1$-tailed $)=0.030]$. So, when reminded about the proponents'

Table 6A. The Influence of the Proponents'Anticipated Joyfulness on Achievement's Motivation

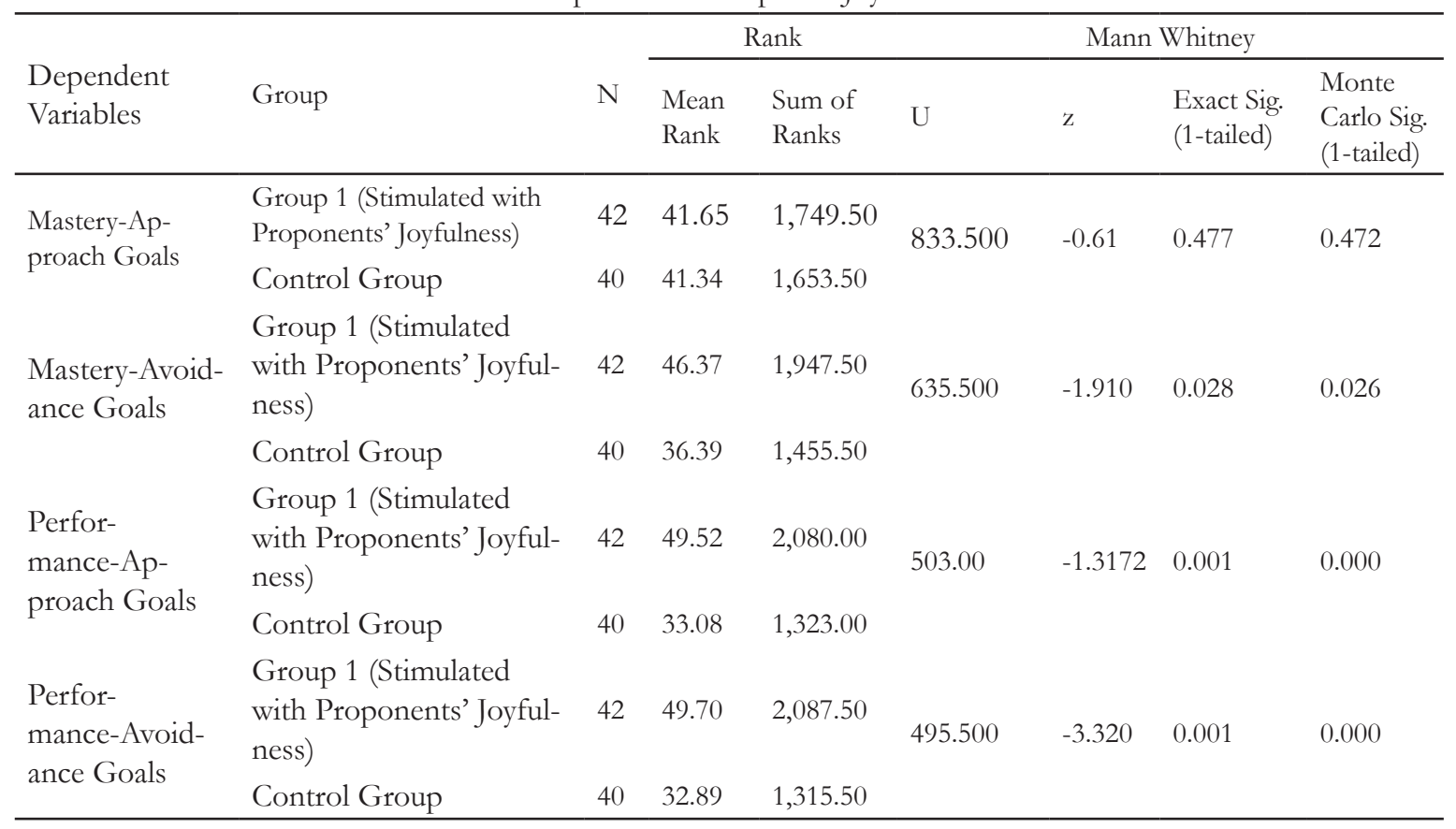

the proponents' joyfulness, was successful in rejecting the null hypothesis for the performance-avoidance $[z=-1.910$, sig. $(1$-tailed $)=0.028]$, performance-approach $[\mathrm{z}$ $=-1.172$, sig. $(1$-tailed $)=0.001]$, and performance-avoidance $[z=-3.320$, sig. $(1$-tailed $)=$ 0.001] goals. Therefore, H1b, H1c, and H1d were confirmed (Table 6A).

Testing H2: The stronger the proponents anticipated distress is; in response to individuals' failure, the higher are the (a) mastery-approach, (b) mastery-avoidance, (c) performance-approach, and (d) performance-avoidance goals.

In Group 4, the experimentation with the proponents' anticipated distress succeeded in increasing the mastery-approach $[\mathrm{z}=-3.32169$, sig. (1-tailed) $=0.000]$, mas- distress, in response to their failure, the participants increased the mastery-approach, mastery-avoidance, performance-approach, and performance-avoidance goals, so $\mathrm{H}_{2 \mathrm{a}}$, $\mathrm{H}_{2 \mathrm{~b}}, \mathrm{H}_{2 \mathrm{c}}$ and $\mathrm{H}_{2 \mathrm{~d}}$ were confirmed (Table 6B).

Testing H3: The stronger the opponents' joyfulness is, anticipated as schadenfreude emotions about the individuals' failure, the higher the performance-avoidance goals are.

The experimentation in Group 2, conducted by reminding the participants about the opponents' joyfulness, described as their schadenfreude about the individuals' failure to increase the performance-avoidance goal, was successful $[z=-1.807$, sig. (1-tailed) $=$ 0.036], and confirmed H3. Additional analysis revealed that the opponents' joyfulness 
Table 6B. The Influence of the Proponents'Anticipated Distress on Achievement's Motivation

\begin{tabular}{|c|c|c|c|c|c|c|c|c|}
\hline \multirow[b]{2}{*}{$\begin{array}{l}\text { Dependent } \\
\text { Variables }\end{array}$} & \multirow[b]{2}{*}{ Group } & \multirow[b]{2}{*}{$\mathrm{N}$} & \multicolumn{2}{|c|}{ Rank } & \multicolumn{4}{|c|}{ Mann Whitney } \\
\hline & & & $\begin{array}{l}\text { Mean } \\
\text { Rank }\end{array}$ & $\begin{array}{l}\text { Sum of } \\
\text { Ranks }\end{array}$ & $\mathrm{U}$ & z & $\begin{array}{l}\text { Exact Sig. } \\
\text { (1-tailed) }\end{array}$ & $\begin{array}{l}\text { Monte } \\
\text { Carlo Sig. } \\
\text { (1-tailed) }\end{array}$ \\
\hline \multirow{2}{*}{$\begin{array}{l}\text { Mastery-Approach } \\
\text { Goals }\end{array}$} & $\begin{array}{l}\text { Group } 4 \text { (Stimulated with } \\
\text { Proponents' Distress) }\end{array}$ & 21 & 36.31 & 762.50 & \multirow[t]{2}{*}{161.500} & \multirow[t]{2}{*}{-3.321} & \multirow[t]{2}{*}{0.000} & \multirow[t]{2}{*}{0.000} \\
\hline & Control Group & 33 & 21.89 & 722.50 & & & & \\
\hline \multirow{2}{*}{$\begin{array}{l}\text { Mastery-Avoid- } \\
\text { ance Goals }\end{array}$} & $\begin{array}{l}\text { Group } 4 \text { (Stimulated with Pro- } \\
\text { ponents' Distress) }\end{array}$ & 21 & 36.88 & 774.50 & \multirow[t]{2}{*}{149.500} & \multirow[t]{2}{*}{-3.534} & \multirow[t]{2}{*}{0.000} & \multirow[t]{2}{*}{0.000} \\
\hline & Control Group & 33 & 21.53 & 710.50 & & & & \\
\hline \multirow{2}{*}{$\begin{array}{l}\text { Perfor- } \\
\text { mance-Ap- } \\
\text { proach Goals }\end{array}$} & $\begin{array}{l}\text { Group } 4 \text { (Stimulated with Pro- } \\
\text { ponents' Distress) }\end{array}$ & 21 & 36.14 & 759.00 & \multirow[t]{2}{*}{165.000} & \multirow[t]{2}{*}{-3.253} & \multirow[t]{2}{*}{0.000} & \multirow[t]{2}{*}{0.000} \\
\hline & Control Group & 33 & 22.00 & 726.00 & & & & \\
\hline \multirow{2}{*}{$\begin{array}{l}\text { Perfor- } \\
\text { mance-Avoid- } \\
\text { ance Goals }\end{array}$} & $\begin{array}{l}\text { Group } 4 \text { (Stimulated with Pro- } \\
\text { ponents' Distress) }\end{array}$ & 21 & 32.12 & 674.50 & \multirow[t]{2}{*}{249.500} & \multirow[t]{2}{*}{-1.740} & \multirow[t]{2}{*}{0.030} & \multirow[t]{2}{*}{0.035} \\
\hline & Control Group & 33 & 24.56 & 810.50 & & & & \\
\hline
\end{tabular}

Table 6C. The Influence of the Opponents' Anticipated Joyfulness on Achievement's Motivation

\begin{tabular}{|c|c|c|c|c|c|c|c|c|}
\hline \multirow[b]{2}{*}{$\begin{array}{l}\text { Dependent } \\
\text { Variables }\end{array}$} & \multirow[b]{2}{*}{ Group } & \multirow[b]{2}{*}{$\mathrm{N}$} & \multicolumn{2}{|c|}{ Rank } & \multicolumn{4}{|c|}{ Mann Whitney } \\
\hline & & & $\begin{array}{l}\text { Mean } \\
\text { Rank }\end{array}$ & $\begin{array}{l}\text { Sum of } \\
\text { Ranks }\end{array}$ & $\mathrm{U}$ & z & $\begin{array}{l}\text { Exact } \\
\text { Sig. } \\
\text { (1-tailed) }\end{array}$ & $\begin{array}{l}\text { Monte } \\
\text { Carlo Sig. } \\
\text { (1-tailed) }\end{array}$ \\
\hline \multirow{2}{*}{$\begin{array}{l}\text { Mastery-Ap- } \\
\text { proach Goals }\end{array}$} & $\begin{array}{l}\text { Group } 2 \text { (Stimulated with } \\
\text { Opponents' Joyfulness) }\end{array}$ & 39 & 39.22 & $1,529.50$ & \multirow[t]{2}{*}{537.500} & \multirow[t]{2}{*}{-1.207} & \multirow[t]{2}{*}{0.115} & \multirow[t]{2}{*}{0.108} \\
\hline & Control Group & 33 & 33.29 & $1,098.50$ & & & & \\
\hline \multirow{2}{*}{$\begin{array}{l}\text { Mastery-Avoid- } \\
\text { ance Goals }\end{array}$} & $\begin{array}{l}\text { Group } 2 \text { (Stimulated with } \\
\text { Proponents' Joyfulness) }\end{array}$ & 39 & 37.54 & $1,464.00$ & \multirow[t]{2}{*}{603.000} & \multirow[t]{2}{*}{-0.462} & \multirow[t]{2}{*}{0.324} & \multirow[t]{2}{*}{0.311} \\
\hline & Control Group & 33 & 35.27 & $1,164.00$ & & & & \\
\hline \multirow{2}{*}{$\begin{array}{l}\text { Perfor- } \\
\text { mance-Ap- } \\
\text { proach Goals }\end{array}$} & $\begin{array}{l}\text { Group } 2 \text { (Stimulated with } \\
\text { Proponents' Joyfulness) }\end{array}$ & 39 & 36.85 & $1,437.00$ & \multirow[t]{2}{*}{630.00} & \multirow[t]{2}{*}{-0.155} & \multirow[t]{2}{*}{0.440} & \multirow[t]{2}{*}{0.428} \\
\hline & Control Group & 33 & 36.09 & $1,191.00$ & & & & \\
\hline \multirow{2}{*}{$\begin{array}{l}\text { Perfor- } \\
\text { mance-Avoid- } \\
\text { ance Goals }\end{array}$} & $\begin{array}{l}\text { Group } 2 \text { (Stimulated with } \\
\text { Proponents' Joyfulness) }\end{array}$ & 39 & 40.56 & $1,582.00$ & \multirow[t]{2}{*}{485.000} & \multirow[t]{2}{*}{-1.807} & \multirow[t]{2}{*}{0.036} & \multirow[t]{2}{*}{0.030} \\
\hline & Control Group & 33 & 31.70 & $1,046.00$ & & & & \\
\hline
\end{tabular}

had a non-significant influence on the mastery-approach $[\mathrm{z}=-1.207$, sig. $(1$-tailed $)=$ $0.115]$, mastery-avoidance $[z=-0.462$, sig. $(1$-tailed $)=0.324]$, and performance-avoidance $[z=-0.115$, sig. $(1$-tailed $)=0.440]$ goals (Table 6C).

Testing H4: The stronger the opponents' distress is, anticipated as social envy of the individuals' success, the higher the performance-approach goals are.
Experimentation with the opponents' distress, described as envy of the individuals' success for Group 3, succeeded in increasing the performance-approach goal $[\mathrm{z}=-1.887$, sig. $(1$-tailed $)=0.030]$, so $\mathrm{H}_{4}$ was confirmed (Table 6D). Additionally, the opponents' distress had no positive influence on the mastery-approach $[\mathrm{z}=-1.366$, sig. $(1$-tailed $)=$ $0.087]$, mastery-avoidance $[z=-0.765$, sig. $(1$-tailed $)=0.224]$, and performance-avoidance $[z=-0.493$, sig. (1-tailed $)=0.314]$ goals. 
Gadjah Mada International Journal of Business - January-April, Vol. 23, No. 1, 2021

Table 6D. The Influence of the Opponents' Anticipated Distress about Achievement

\begin{tabular}{|c|c|c|c|c|c|c|c|c|}
\hline \multirow{2}{*}{$\begin{array}{l}\text { Dependent } \\
\text { Variables }\end{array}$} & \multirow[b]{2}{*}{ Group } & \multirow[b]{2}{*}{$\mathrm{N}$} & \multicolumn{2}{|c|}{ Rank } & \multicolumn{4}{|c|}{ Mann Whitney } \\
\hline & & & $\begin{array}{l}\text { Mean } \\
\text { Rank }\end{array}$ & $\begin{array}{l}\text { Sum of } \\
\text { Ranks }\end{array}$ & $\mathrm{U}$ & z & $\begin{array}{l}\text { Exact Sig. } \\
\text { (1-tailed) }\end{array}$ & $\begin{array}{l}\text { Monte Carlo } \\
\text { Sig. (1-tailed) }\end{array}$ \\
\hline \multirow[t]{2}{*}{$\begin{array}{l}\text { Mastery-Ap- } \\
\text { proach Goals }\end{array}$} & $\begin{array}{l}\text { Group } 3 \text { (Stimulated } \\
\text { with Opponents' } \\
\text { Distress) }\end{array}$ & 28 & 38.36 & $1,074.00$ & \multirow[t]{2}{*}{452.00} & \multirow[t]{2}{*}{-1.366} & \multirow[t]{2}{*}{0.087} & \multirow[t]{2}{*}{0.079} \\
\hline & Control Group & 40 & 31.80 & $1,272.00$ & & & & \\
\hline $\begin{array}{l}\text { Mas- } \\
\text { tery-Avoidance }\end{array}$ & $\begin{array}{l}\text { Group } 3 \text { (Stimulated with } \\
\text { Proponents' Distress) }\end{array}$ & 28 & 36.68 & $1,027.00$ & \multirow[t]{2}{*}{499.000} & \multirow[t]{2}{*}{-0.765} & \multirow[t]{2}{*}{0.224} & \multirow[t]{2}{*}{0.201} \\
\hline Goals & Control Group & 40 & 32.98 & $1,319.00$ & & & & \\
\hline \multirow{2}{*}{$\begin{array}{l}\text { Perfor- } \\
\text { mance-Ap- } \\
\text { proach Goals }\end{array}$} & $\begin{array}{l}\text { Group } 3 \text { (Stimulated with } \\
\text { Proponents' Distress) }\end{array}$ & 28 & 39.80 & $1,114.50$ & \multirow[t]{2}{*}{411.500} & \multirow[t]{2}{*}{-1.887} & \multirow[t]{2}{*}{.030} & \multirow[t]{2}{*}{0.028} \\
\hline & Control Group & 40 & 30.79 & $1,231.50$ & & & & \\
\hline \multirow{2}{*}{$\begin{array}{l}\text { Perfor- } \\
\text { mance-Avoid- } \\
\text { ance Goals }\end{array}$} & $\begin{array}{l}\text { Group } 3 \text { (Stimulated with } \\
\text { Proponents' Distress) }\end{array}$ & 28 & 35.89 & $1,005.00$ & \multirow[t]{2}{*}{521.00} & \multirow[t]{2}{*}{-0.493} & \multirow[t]{2}{*}{0.314} & \multirow[t]{2}{*}{0.302} \\
\hline & Control Group & 40 & 33.53 & $1,341.00$ & & & & \\
\hline
\end{tabular}

Mediation Effect

\section{Preview}

The mediation effect of self-efficacy on the influence of the anticipated emotions of other people (AEOP) on achievement goals is visualized in Figure 1. To test the mediating effect, the author used the three traditional equations specified by Kenny (2018). For the simple mediation, the equations were:

$$
\begin{gathered}
Y=i_{1}+c X+e_{i}(7) \\
M=i_{2}+a X+e_{2}(8) \\
Y=i_{3}+b M+c^{\prime} X+e_{3}(9)
\end{gathered}
$$

Coefficient $c$ in Equation (7) represents the total effect of $X$ (experimentation) on the dependent variable $Y$ (achievement goals). According to Miočević, Gonzalez, Valente, and MacKinnon (2018), the total effect is derived from $c^{\prime}+a+b$. Coefficient $a$ in Equation (8) denotes the influence of $X$ on $M$ (self-efficacy). Coefficient $b$ represents the influence of $M$ on $Y$. Coefficient $c$ 'represents the effect of $X$ on $Y$ when $M$ is included in the equation. The $i_{1}, i_{2}$, and $i_{3}$ are constants or intercepts, whereas $e_{1}, e_{2}$, and $e_{3}$ represent the equations' residual.
The mediation effect can be calculated through the indirect effect generated by extracting c' from c or c-c' and multiplying a by $\mathrm{b}$ or ab. However, although it makes sense, Preacher and Hayes (2004) said that there is no specific explanation to calculate c-c'. For that reason, Zhao, Lynch, and Chen (2010) said that the significance of $a b$ is the starting point of investigation and the only requirement is to analyze the mediation effect. If $a b$ is significant, we need to check c' and the direction (positive or negative) of a $\mathrm{x} b \mathrm{x} \mathrm{c}^{\prime}$ to determine the type of mediation.

Besides the mediating effect measured by traditional mediation analysis, the Bayesian method also deals with the potential mediation effect given by the interaction of $X$ and $M$. This interaction is checked to investigate whether the mediation effect varies for the different levels of the independent variables (Miočević, Gonzalez, Valente and MacKinnon, 2018). The coefficient $b$ represents the interaction effect of $X$ and $M$ or $X . M$, as shown in Equation (10).

$$
Y=i_{4}+b M+c^{\prime} X+h X M+e_{4}
$$


(A) $\operatorname{AEOP}(\mathrm{X}) \longrightarrow \mathrm{c} \longrightarrow \begin{gathered}\text { Achievement } \\ \text { Goals }(\mathrm{Y})\end{gathered}$

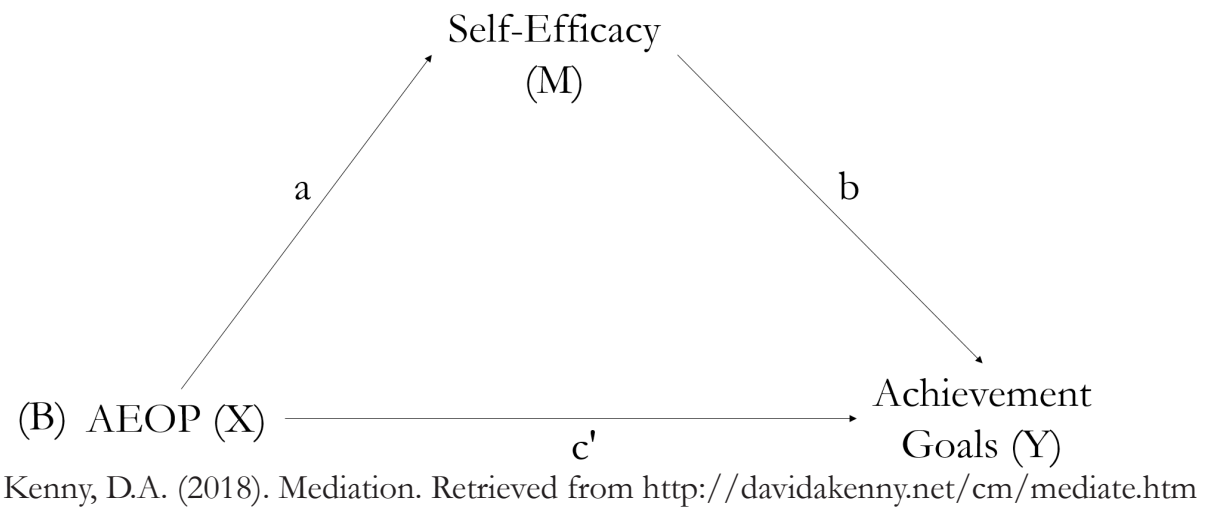

Figure 1. Simple Mediation Model

Further investigation can also include a moderating variable, such as gender, to find whether the mediation effect is different for different levels of the moderating variables.

To determine the indirect effect's significance, traditionally, the researchers compare the statistic $z$ with a critical point at a particular type I error or significance level. The use of this statistic means that the normal distribution of $a b$ is taken for granted. However, this approach, which simply divides the coefficient by the root of its error standard, potentially creates a bias because the distribution of $a b$ is usually skewed (Preacher and Hayes 2004; Zhao 2004). To overcome this problem, first, besides the significance value of the coefficient, the information about the confidence limit for $z$ and $M$ is required (MacKinnon, Lockwood, and Williams 2004). Second, bootstrapping is required, especially for small to moderate samples (MacKinnon, Lockwood, and Williams 2004; Preacher and Hayes 2004). With bootstrapping, hypothesis testing can be conducted even though the distribution of $a b$ is unknown (Preacher and Hayes 2004).

The indirect effect's significance can be concluded through the confidence inter- val (for example, 95\% for the bootstrapping coefficient). If the confidence interval does not intersect with zero, the indirect effect is significant (Preacher and Hayes 2004; Zhao, Lynch, and Chen 2010).

The bootstrapping and calculation of the total effect, direct effect, indirect effect, interaction effect, and moderation effect used the algorithm developed by Preacher and Hayes (2004). This study used 5,000 times bootstrapping, which is viewed as normal practice by Zhao, Lynch, and Chen (2010). For that purpose, the author utilized Hayes's (2020) macro regression application called Process version 3.5, plugged in SPSS 22 , with a confidence level of $95 \%$.

\section{Testing Hypothesis 5}

In Hypothesis 5, the author specified that self-efficacy had no mediation effect on the influence of proponents' joyfulness on the (a) mastery-approach, (b) mastery-avoidance, (c) performance-approach, and (d) performance-avoidance goals. As displayed in Tabel 7, the direct effect was not significant ( $\left.c^{\prime}=-0.175, \mathrm{t}=-1.052, \alpha=0.296\right)$. Therefore, the indirect effect was deter- 
Gadjah Mada International Journal of Business - January-April, Vol. 23, No. 1, 2021

mined through a partial standardized effect concerning the mastery-approach goals. The statistic $\mathrm{m}=0.2383$, lies in the interval of 0.0429 to 0.4637 (confidence level $=95 \%$ ), and does not intersect with 0 , indicating that the indirect effect was significant, contrary to the previous expectation specified in $\mathrm{H} 5 \mathrm{a}$.

According to Zhao, Lynch, and Chen (2010), there should be indirect-only mediation in this process since the direct effect was not significant. Additional analysis showed that gender had no moderating effect on the mediation because the difference in mediation between males and females was not significant $(\mathrm{m}=0.0204$, CI $95 \%$ : -0.2811 to 0.2866) (Table 7).

Concerning joyfulness and the mastery-avoidance goals, the self-efficacy mediation analysis of their relationship started with a direct effect that was not significant ( $c^{\prime}=$
$0.295, \mathrm{t}=0.209, \alpha=0.233)$. The indirect effect was also not significant, as indicated by the coefficient $\mathrm{m}=0.076$, which lies in the interval of -0.1190 to 0.3298 . It meant that with a $95 \%$ confidence level, $\mathrm{m}$ did intersect with 0 and, therefore, must be categorized as not significant. Further analysis showed that the result was not moderated by gender $(\mathrm{m}=$ 0.085, CI 95\%: -0.2811 to 0.2866). Therefore, Hypothesis H5b was confirmed.

The indirect effect on the performance-approach goals was significant $(\mathrm{m}=$ 0.180, CI 95\%: 0.0225 to 0.4465 ). This result was contrary to the expectation specified by H5c. We could also see that the direct effect was significant $\left(c^{\prime}=0.526, t=2.812, \alpha=\right.$ $0.006)$, and the value of $a \times b \times c(3.475 \mathrm{x}$ $0.052 \times 0.526=0.095)$ was positive. According to Zhao, Lynch, and Chen (2010), there should be a complementary mediation of self-efficacy in the relationship of concern.

Table 7. The Mediation Effect of Self-Efficacy on the Influence of Proponents' Anticipated Joyfulness on Achievement Goals with Confidence Level of 95\%

\begin{tabular}{|c|c|c|c|c|c|c|}
\hline & & \multicolumn{5}{|c|}{ Outcome } \\
\hline & & M & MAP & MAV & PAP & PAV \\
\hline \multicolumn{7}{|c|}{ Testing Hypothesis H5 } \\
\hline \multirow[t]{3}{*}{ M } & & & $\mathrm{b}=0.052$ & $\mathrm{~b}=0.022$ & $\mathrm{~b}=0.052$ & $\mathrm{~b}=0.036$ \\
\hline & & & $\mathrm{t}=4.029$ & $t=1.142$ & $\mathrm{t}=3.549$ & $t=2.404$ \\
\hline & & & $\alpha=0.000$ & $\alpha=0.256$ & $\alpha=0.000$ & $\alpha=0.018$ \\
\hline \multirow[t]{12}{*}{$\mathrm{X}$} & Total Effect & $\mathrm{a}=3.475$ & $c=0.007$ & $\mathrm{c}=0.37$ & $c=0.706$ & $c=0.601$ \\
\hline & & $\mathrm{t}=2.520$ & $\mathrm{t}=0.039$ & $\mathrm{t}=1.57$ & $t=3.665$ & $t=3.145$ \\
\hline & & $\alpha=0.028$ & $\alpha=0.969$ & $\alpha=0.121$ & $\alpha=0.000$ & $\alpha=0.001$ \\
\hline & Direct Effect & & $c^{\prime}=-0.175$ & $c^{\prime}=0,295$ & $c^{\prime}=0.526$ & $c^{\prime}=0.475$ \\
\hline & & & $\mathrm{t}=-1.052$ & $\mathrm{t}=1.209$ & $\mathrm{t}=2.812$ & $t=2.464$ \\
\hline & & & $\alpha=0.296$ & $\alpha=0.233$ & $\alpha=0.006$ & $\alpha=0.016$ \\
\hline & Indirect Effect & & $\mathrm{m}=0.1821$ & $\mathrm{~m}=0.076$ & $\mathrm{~m}=0.180$ & $\mathrm{~m}=0.1258$ \\
\hline & & & BootLLCI $=0.0330$ & $\begin{array}{l}\text { BootLLCI }= \\
-0.1190\end{array}$ & BootLLCI $=0.0225$ & BootLLCI $=-0.0081$ \\
\hline & & & BootULCI $=0.3698$ & BootULCI $=0.3298$ & BootULCI $=0.4465$ & BootULCI $=0.3780$ \\
\hline & Partial Stan- & & $\mathrm{m}=0.2313$ & $\mathrm{~m}=0.0703$ & $\mathrm{~m}=0.1922$ & $\mathrm{~m}=0.1380$ \\
\hline & $\begin{array}{l}\text { dardized Indi- } \\
\text { rect Effect }\end{array}$ & & BootLLCI $=0.0429$ & $\begin{array}{l}\text { BootLLCI }= \\
-0.0959\end{array}$ & BootLLCI $=0.0245$ & BootLLCI $=-0.0083$ \\
\hline & & & BootULCI $=0.4637$ & BootULCI $=0.3097$ & BootULCI $=0.4301$ & BootULCI $=0.4203$ \\
\hline
\end{tabular}


X.W Indirect Effect (Males)

Indirect Effect (Females)

Different between Males and Females

X.M Interaction

Effect

Testing Hypothesis 6

M

Total Effect

Direct Effect

Indirect Effect

Partial Stan-

dardized Indirect Effect

X.W Indirect Effect (Males)

Indirect Effect (Females)

Different between Males and Females $\mathrm{m}=1.444$
BootLLCI $=$
-0.0483

$\mathrm{m}=0.0602$

BootLLCI =

$-0.1160$

BootULCI $=0.3739$

$\mathrm{m}=0.1648$

BootLLCI $=$ $-0.0288$

BootULCI $=0.3888$

$\mathrm{m}=0.0204$

BootLLCI $=$ $-0.2811$

BootULCI $=0.2866$

$\mathrm{F}=0.392$

$\alpha=0.533$

BootULCI $=0.3614$

$\mathrm{m}=0.0687$

BootLLCI = $-0.0803$

BootULCI $=0.3614$

$\mathrm{m}=0.085$

BootLLCI = $-0.1242$

BootULCI $=0.2683$

$\mathrm{b}=0.052$

$\mathrm{t}=2.461$

$\alpha=0.009$

$$
\mathrm{a}=5.320 \quad \mathrm{c}=0.746
$$

$\mathrm{t}=3.569$

$\alpha=0.000 \quad \alpha=0.000$

$c^{\prime}=0.470$

$\mathrm{t}=2.051$

$\alpha=0.046$

$\mathrm{m}=0.2764$

BootLLCI $=0.0326$

BootULCI $=0.6358$

$\mathrm{m}=0.3340$

BootLLCI $=0.0476$

BootULCI $=0.7168$

$\mathrm{m}=0.1883$

BootLLCI $=0.0154$

$\mathrm{F}=0.947$

$\alpha=0.334$

$\mathrm{b}=0.049$

$\mathrm{t}=2.137$

$\alpha=0.030$

$\mathrm{c}=0.817$

$\mathrm{t}=3.646$

$\alpha=0.002$

$c^{\prime}=0.556$

$\mathrm{t}=2.237$

$\alpha=0.030$

$\mathrm{m}=0.2606$

BootLLCI $=0.0163$

BootULCI $=0.5759$

$\mathrm{m}=0.2926$

BootLLCI $=0.0191$

BootULCI $=0.4424$

$\mathrm{m}=0.3868$

BootLLCI $=0.0298$$$
\text { Boo }
$$$$
\mathrm{m}=0.3646
$$

BootULCI $=1.0171$

$\mathrm{m}=0.1985$

BootLLCI $=$ $-0.0519$

BootULCI $=0.7062$

$\mathrm{F}=1.093$
$\alpha=0.301$

$F=1.093$
$\alpha=0.301$$$
\text { BootLLCI }
$$
$\mathrm{m}=0.1428$
BootLLCI $=$
-0.0475

BootULCI $=0.3948 \quad$ BootULCI $=0.3237$

$\mathrm{m}=0.1629$

$\mathrm{m}=0.1138$

BootLLCI $=-.0271$

BootLLCI $=-0.0148$

BootULCI $=0.4352 \quad$ BootULCI $=0.4190$

$\mathrm{m}=0.0201$

BootLLCI = $-0.2626$

$\mathrm{m}=0.0141$

BootLLCI $=-0.1573$

BootULCI $=0.3164 \quad$ BootULCI $=0.3063$

$\mathrm{F}=0.082$

$\alpha=0.775$

$\mathrm{F}=0.491$

$\alpha=0.486$

$\mathrm{b}=0.044$

$\mathrm{b}=0.031$

$\mathrm{t}=1.553$

$\alpha=0.127$

$\mathrm{t}=1.203$

$\alpha=0.235$

$\mathrm{c}=0.873$

$\mathrm{c}=0.415$

$\mathrm{t}=3.189$

$\mathrm{t}=3.188$

$\alpha=0.002$

$c^{\prime}=0.637$

$\mathrm{t}=2.053$

$\alpha=0.045$

$\alpha=0.002$

$c^{\prime}=0.266$

$\mathrm{t}=0.946$

$\mathrm{m}=0.2362$

$\alpha=0.349$

BootLLCI $=-0.0166$

BootULCI $=0.6193$

$\mathrm{m}=0.2223$

BootLLCI $=$ $-0.0191$

BootULCI $=0.5561 \quad$ BootULCI $=0.4936$

$\mathrm{m}=0.1609$

$\mathrm{m}=0.1129$

BootLLCI =

BootLLCI $=-0.0457$ $-0.1609$

$\mathrm{m}=0.3304$

BootULCI $=0.3441$

BootLLCI $=$ $-0.0166$

$$
\text { BoO }
$$$$
\mathrm{m}=0.1695
$$$$
\text { BootLLCI = }
$$$$
-0.0464
$$$$
\mathrm{m}=0.2319
$$$$
\text { BootLLCI }=-0.0747
$$

BootULCI $=0.6764$

$$
\begin{array}{ll}
\text { BootULCI }=0.6764 & \text { BootULC } \\
\mathrm{F}=0.633 & \mathrm{~F}=0.011
\end{array}
$$

$\alpha=0.430$

$\alpha=0.918$

Notes.X = Independent variable, $\mathrm{M}=$ Self-Efficacy, $\mathrm{X} . \mathrm{M}=$ interaction of $\mathrm{X}$ and $\mathrm{M}, \mathrm{W}=$ Gender, $\mathrm{MAP}=$ mastery-approach goals, MAV = mastery-avoidance goals, $\mathrm{PAP}=$ performance-approach goals. 
Gadjah Mada International Journal of Business - January-April, Vol. 23, No. 1, 2021

Subsequent analysis indicated that the mediation of males and females was not different $(\mathrm{m}=0.0201$, CI 95\%: -0.2626 to 0.3164).

With the coefficient $m=0.1258$ (and with $95 \%$ confidence level), which lies in the interval of -0.0081 to 0.3780 , the mediation effect of self-efficacy on the influence of proponents' anticipated joyfulness on the performance-avoidance goal, as specified in H5d, was not significant. Subsequent analysis showed that the potential mediation effect of $\mathrm{X}$ and M's interaction was not significant $(\mathrm{F}=$ $0.011, \alpha=0.918)$. There was also no gender moderation for this result $(\mathrm{m}=0.1190,95 \%$ CI: -0.0670 to 0.4483 ). In sum, the above analysis asserts that self-efficacy mediates the influence of the proponent's anticipated joyfulness on the mastery-approach and performance-approach goals with the complementary mediation.

\section{Testing Hypothesis 6}

The author expected, with Hypothesis H6, that self-efficacy would mediate the influence of the proponents' anticipated distress on the (a) mastery-approach, (b) mastery-avoidance, (c) performance-approach, and (d) performance-avoidance goals. As exhibited in Table 7, the indirect effect concerning the mastery-approach was significant $(\mathrm{m}=0.276$, CI 95\%: 0.0154 to 0.4424), and there was enough evidence to accept H6a. Because the direct effect was also significant $\left(c^{\prime}=0.556, \mathrm{t}=2.237, \alpha=0.030\right)$ and $a \times b$ $x c(5.320 \times 0.052 \times 0.746=0.206)$ was positive, according to Zhao, Lynch, and Chen (2010), then we found a complementary mediation with this analysis. Subsequent analysis showed that $\mathrm{X}$ and M's potential interaction effect was not significant $(F=1.093, \alpha=$ $0.301)$. There was also no gender moderation $(\mathrm{m}=0.1985$, CI 95\%: -0.0519 to 0.7062).
The same result was also found in the mediation related to the mastery-avoidance goal $(\mathrm{m}=0.2606$, CI 95\%: 0.0163 to 0.5759$)$, so Hypothesis $6 \mathrm{~b}$ was confirmed. Since the direct effect was significant $\left(c^{\prime}=0.637, \mathrm{t}=\right.$ 2.053, $\alpha=0.037$ ) and the value of $a \times b \times$ $c^{\prime}(5.320 \times 0.049 \times 0.556=0.145)$ was positive, as specified by Zhao, Lynch, and Chen (2010), in this case, we found a complementary mediation. Further analysis showed that $\mathrm{X}$ and M's interaction had no mediating effect $(F=0.819, \alpha=0.370)$. There was also no moderation by gender $(\mathrm{m}=1.871$, CI $95 \%=$ -0.0140 to 0.5698$)$.

As we can see in Table 7, the influence of the proponents' anticipated distress on the performance-approach goal specified in H6c was not confirmed ( $\mathrm{m}=0.2362$, CI 95\%: -0.0191 to 0.5561$)$. When the mediation was moderated by gender, the same result also occurred since the mediation by males ( $\mathrm{m}=0.1609$, CI 95\%: -0.1609 to 0.4238 ) and females ( $\mathrm{m}=0.3304$, CI 95\%: -0.0166 to 0.9673 ) was not significant. There was also no interaction effect of $\mathrm{X}$ and $\mathrm{M}$ on the mediation.

The same result was also found for the performance-avoidance goals. As shown in Table 7 , the mediation coefficient $(m=$ 0.1657 , CI $95 \%$ : -0.0626 to 0.4659 ) was not significant, and there was no reason to accept H6d. Further analysis showed that the result was not moderated by gender as the mediation effects by males ( $\mathrm{m}=0.1129$, CI 95\%: 0-0.0457 to 0.3441) and females ( $\mathrm{m}=$ -0.0747 to 0.7194 ) were not significant. The interaction between $\mathrm{X}$ and $\mathrm{M}$ also showed no effect $(F=0.011, \alpha=0.918)$. In sum, self-efficacy only mediated the influence of the proponents' anticipated distress on the mastery-approach and mastery-avoidance goals. 


\section{Testing Hypothesis 7}

Hypothesis 7 specified that self-efficacy mediated the influence of the opponents' joyfulness on the performance-avoidance goal. As shown in Table 8, the median effect concerning the performance-avoidance goal was not significant $(m=0.0941$, CI 95\%: -0.0135 to 0.2646 ), so Hypothesis 7 was not confirmed. The potential mediation effect given the interaction of $X$ and $M$ cannot be expected since the interaction effect was not significant $(F=0.155, \alpha=0.95)$. We can also believe that the mediation effect by males ( $m$ $=0.1063$, CI 95\%: -0.0551 to 0.3076$)$ and females ( $m=0.0782$, CI 95\%: -0.0954 to 0.3187 ) was the same since the difference between the two segments was not significant $(\mathrm{m}=-0.0281$, CI 95\%: -0.2669 to 0.2514$)$.

Table 8. The Median Effect of Self-Efficacy on the Influence of Opponents' Anticipated Joyfulness and Distress on Achievement's Motivation with a Confidence Level of 95\%

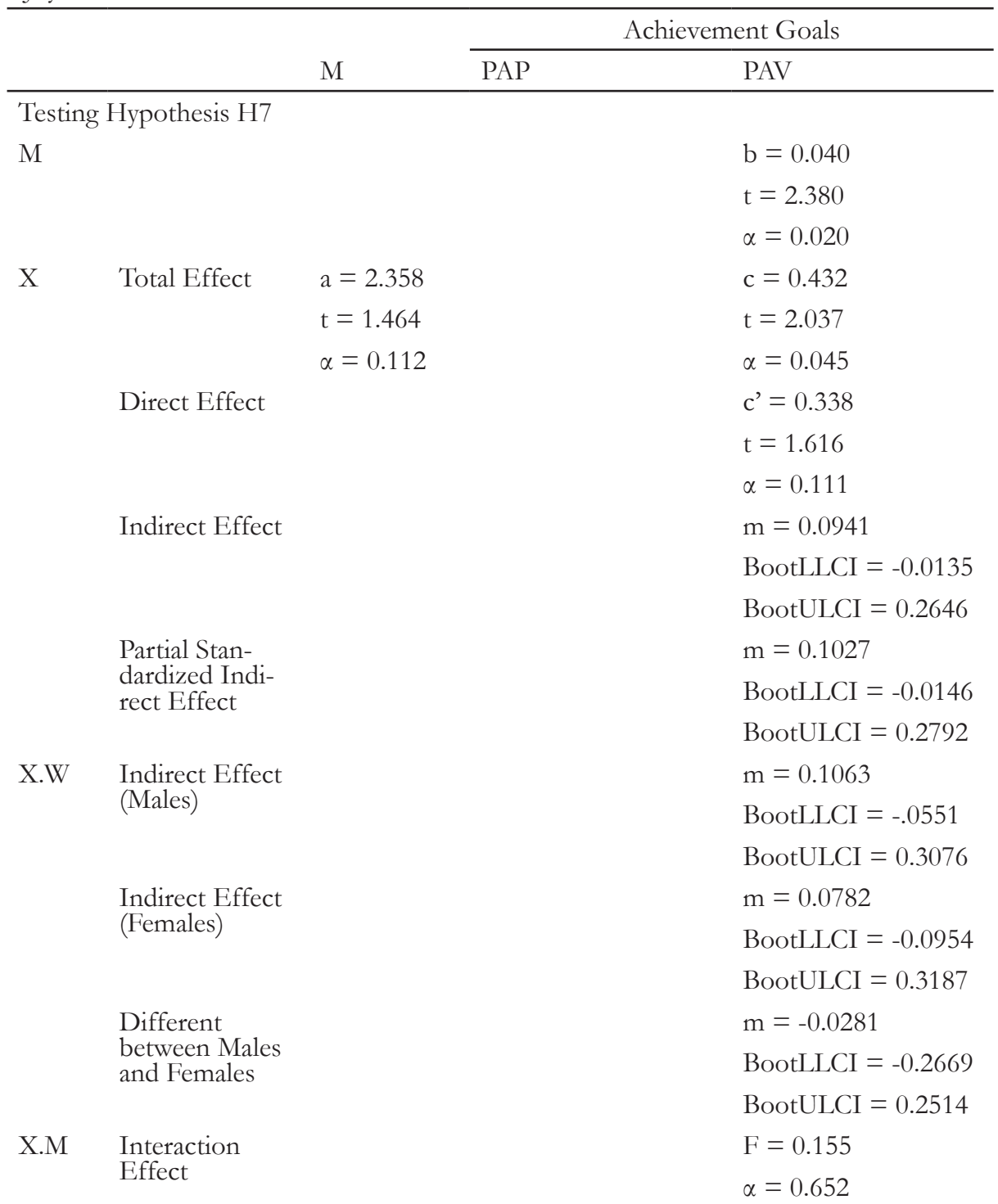




$$
\begin{aligned}
& \text { Testing Hypothesis } 8 \\
& \mathrm{M} \\
& \mathrm{b}=0.065 \\
& \mathrm{t}=4.166 \\
& \alpha=0.000 \\
& \mathrm{X} \quad \text { Total Effect } \quad \mathrm{a}=1.511 \quad \mathrm{c}=441 \\
& \mathrm{t}=0.991 \quad \mathrm{t}=2.049 \\
& \alpha=0.325 \quad \alpha=0.044 \\
& \text { Direct Effect } \quad c^{\prime}=0.343 \\
& \mathrm{t}=1.768 \\
& \alpha=0.082 \\
& \text { Indirect Effect } \quad \mathrm{m}=0.0978 \\
& \text { BootLLCI }=-0.0788 \\
& \text { BootULCI }=0.3478 \\
& \text { Partial Stan- } \quad \mathrm{m}=0.1095 \\
& \begin{array}{ll}
\text { dardized Indi- } & \text { BootLLCI }=-0.0935
\end{array} \\
& \text { rect Effect } \quad \text { BootULCI }=0.3774 \\
& \text { X.W Indirect Effect } \mathrm{m}=0.2895 \\
& \text { (Males) BootLLCI }=-0.0051 \\
& \text { BootULCI }=0.7355 \\
& \text { Indirect Effect } \quad \mathrm{m}=-0.0428 \\
& \text { (Females) BootLLCI }=-0.2971 \\
& \text { BootULCI }=0.2096 \\
& \text { Different } \mathrm{m}=-0.3323 \\
& \begin{array}{ll}
\text { between Males } & \text { BootLLCI }=-0.8489 \\
\text { and Females } & \text { Boot }
\end{array} \\
& \begin{array}{ll}
\text { X.M } & F=0.756
\end{array} \\
& \alpha=0.388
\end{aligned}
$$

Notes. $\mathrm{X}=$ Independent variable, $\mathrm{M}=$ mediating variable (self-efficacy), $\mathrm{X} . \mathrm{M}=$ interaction of $\mathrm{X}$ and $\mathrm{M}, \mathrm{G}=$ Gender

\section{Testing Hypothesis 8}

The author specified the absence of the mediation effect's self-efficacy (M) on the influence of the proponents' anticipated distress $(\mathrm{X})$ on the performance-approach goal (Y) in $\mathrm{H} 8$, so this hypothesis was satisfied. The indirect effect of $\mathrm{X}$ on $\mathrm{Y}$ was not significant, as shown by the partial standardized indirect effect used because of the non-significant indirect effect $(\mathrm{m}=0.1095$, CI 95\%: -0.0935 to 0.3774$)$. The interaction between $\mathrm{X}$ and $\mathrm{M}$ was also not significant $(\mathrm{F}=0.756$, $\alpha=0.388)$. This result ended the expecta- tions for a potential mediation effect. Further analysis showed that the mediation effect was not significant in males ( $\mathrm{m}=0.295$, CI 95\%: -0.0051 to 0.7355$)$ and females $(\mathrm{m}=-0.0428$, CI 95\%:-0.2971 to 0.2096) segments (Table 8).

\section{Discussion}

The Influence of Proponents' Anticipated Emotions on Achievement Goals

This study found that proponents' joyfulness, caused by the scenario of fu- 
ture success, increased the mastery-avoidance, performance-approach, and performance-avoidance goals. These results confirmed the notion that performance-approach and performance-avoidance goals had a high social value for significant others (Dompnier, Darnon, and Butera 2013; Chen et al., 2009). Individuals see that striving for performance-approach and performance-avoidance goals has social utility and desirability (Dompnier, Darnon, and Butera 2013). This result supports Liem and Nie's (2008) study, which found that Indonesian students are indoctrinated significantly with those goal orientations.

In response to the participants' failure scenario, the proponents' anticipated distress succeeded in increasing the mastery-approach, mastery-avoidance, performance-approach, and performance-avoidance goals. This result can be explained using Alicke and Sedikides's (2009) self-protection theory that describes how people increase their motivation to protect themselves from negative selfviews. As we know, in Asian countries, if a duty is perceived to be an individual's obligation to his/her family, the failure to perform it will harm the individual's image amid their family members (Chen et al., 2009). Increasing the achievement goals is done in order to avoid this risk.

In interpersonal relations, based on van der Schalk et al., (2015), Schneider et al., (2017), and Zeelenberg (2018), an anticipated success that produces proponents' joyfulness should be responded to with anticipated pride. On the other hand, anticipated failure followed by the proponents' distress should give birth to anticipated guilt or regret. Individuals will manage their behavior to get anticipated pride or to avoid anticipated guilt. When behavioral management has accept- ed the introjected regulation, those extrinsic goals will be internalized as intrinsic goals. A self-regulation mechanism, to organize personal resources when responding to external stimuli, will be automatically activated (Ryan and Deci 2017; Thøgersen 2006), as found in this study.

\section{The Influence of Opponents' Antici- pated Emotions on Achievement Goals}

Opponents' anticipated distress, caused by individuals' successes (Group 3), may increase the participants' aggressiveness, as indicated by the increase in the performance-approach goals. This result confirms the notion that the performance-approach goal reflects the need to outperform others (Ames 1992; Eliot 1999; Murayama, Eliot, and Yamagata 2011), especially in a competitive system where the rivals' misfortune indirectly increases one's opportunity to get a promotion. Besides, it also indicates the need to be envied by the enviers. Such behavior is typical when achievement is viewed as prestige (van de Ven and Zeelenberg 2020). People can intentionally stimulate enviers' envy by increasing their relative performance (Leahy 2020; van de Ven and Zeelenberg 2020).

Reminding the participants of the opponents' joyfulness, caused by their anticipated failure (Group 2), triggered the performance-avoidance goal. This result is in line with Ladd (2017), who reported that students signal a willingness to not be the object of open and silent bullying caused by their low academic achievements. The increase in the performance-avoidance goal in this study is viewed as a reflection of that motive. Such a response also confirms the coping strategy specified in the protection motivation theory. In this theory, Maddux and Roger (1983) 
Gadjah Mada International Journal of Business - January-April, Vol. 23, No. 1, 2021

underlined that people would protect themselves by maintaining their self-esteem, when threatened psychologically.

\section{The Influence on Self-Efficacy}

As exhibited in Table 7, Bayesian's estimation technique, as utilized in mediation analysis, gives interesting additional findings in which the proponents' anticipated joyfulness $(\mathrm{a}=3.475, \mathrm{t}=2.520, \alpha=0.028)$ and distress $(\mathrm{a}=5.320, \mathrm{t}=4.059, \alpha=0.000)$ are successful in increasing self-efficacy, whereas the opponents' anticipated joyfulness ( $\mathrm{a}=$ 2.358, $\mathrm{t}=1.464, \alpha=0.112$ ) and distress (a $=1.511, \mathrm{t}=0.991, \alpha=0.325)$ fail to do so. These results strengthen the notion that the expected outcomes could change self-efficacy (Seifert and Sutton 2009). The more valuable the outcomes are, the higher is the increase in self-efficacy, and vice versa (Maddux and Rogers 1983). Therefore, the proponents' anticipated joyfulness and distress from succeeding in enhancing their self-efficacy are the outcomes, in which the success to create (make a gain) or avoid them (have no lose) creates significant meaning. Conversely, the opponents' joyfulness and distress have less significant meaning if they fail to increase self-efficacy.

In interpersonal relations, based on van der Schalk et al., (2015), Schneider et al., (2017), and Zeelenberg (2018), an anticipated success that produces proponents' joyfulness should be responded to with anticipated pride. On the other hand, anticipated failure followed by the proponents' distress should come with anticipated guilt or regret. Individuals will manage their behavior to get anticipated pride or to avoid anticipated guilt. When behavioral management accepts the introjected regulation, in which the goals have been internalized, the self-regulation mechanism used to organize personal resources will automatically start (Ryan and Deci 2017; Thøgersen 2006).

The essential function of regulating one's emotions is to establish conditions for being able to anticipate future emotions and modify their behavior to evoke the desired emotions and avoid undesirable ones (Baumgarner, Pieters, and Bagozzi 2007; Tamir and Bigman 2018). Following this argument, the author believes that proponents' anticipated joyfulness and distress function as automatic effects and increase self-efficacy unconsciously through the introjected regulation mechanism, as prescribed in the self-determination theory (Ryan and Deci 2017).

\section{The Mediation of Self-Efficacy}

Self-efficacy is found to mediate: (1) The influence of the proponent's anticipated joyfulness on the mastery-approach and performance-approach goals. (2) The influence of the proponents' anticipated distress on the mastery-approach and mastery-avoidance goals. These results show that the two determinants have different behavior. The first result is coherent with the idea that achievement can function as a gift (Simamora, 2016) and it is the true achievement goals, consisting of the mastery and performance goals (Ames 1992, Nichols 1984), which take that function. Alicke and Sedikides' (2009) self-enhancement theory accordingly states that to make others feel good about themselves, people will increase their motivation and this increase can be preceded by an increase in self-efficacy (Maddux and Rogers 1983).

Concerning the second result, the reasons behind the mediation function of self-efficacy can be traced to Harackiezwicz 
et al., (2002) and Putarek and Pavlin-Bernardić (2020). People with mastery goals tend to accept challenging tasks, to attain new skills. When facing a challenge, they also focus on learning and self-improvement. Consequently, when reminded of the proponents' distress and they see them as a challenge; individuals will increase their self-efficacy to cope. The increase in their self-efficacy contributes partly to the mastery-approach goal's increase.

The second part of this result, i.e., the complementary mediation of self-efficacy on the proponents' anticipated distress and its influence on performance-avoidance goals is quite intriguing. Not as found in this study, but based on a meta-analysis of 125 studies, Huang (2016) found that the correlation between self-efficacy and mastery-avoidance was low. However, it is the study's context that may make a difference and Huang's (2016) meta-analysis was not context-specific. The present study is marked by two specific characteristics. First, mastery-avoidance is induced by the proponents' anticipated distress. Second, the failure described as the cause of that unpleasant emotion is in the Intermediate Accounting class, in which skill-related factors greatly determined the achievement (Nichols 1984; Ames 1992). To protect the proponents from the threat of failure to master the subject, based on Maddux and Rogers (1983), the students increased their self-efficacy by which their mastery-avoidance goals are increased as well.

\section{General Discussion}

The study's results indicate the co-existent of avoidance and approach goals' orientations in Group 1 and Group 4. Grant and Wrzesniewski's (2010) two-dimensional other people's oriented personality trait can explain this co-existence. They said that when the other people-oriented trait is high, people activate their anticipated guilt and anticipated gratitude simultaneously. Asian people frequently show these traits (Chen et al., 2009), and their joint presence can be understood. However, Chasiotis et al., (2019) said that the activation of approach and avoidance goals' orientations could be part of a person's emotional regulation. This study goes a step further, to a position where the proponents' anticipated emotions can also induce that joint presence. Therefore, besides the high other pople-oriented personalities, the co-existence of approach and avoidance motivation are also generated by the regulation of the proponents-oriented emotions.

This study also arrives at a point where a particular goal's orientation can also activate the approach and avoidance motivation exclusively. Van Yperen (2006) and Harackiewizc et al., (2002) said that most individuals (about $85 \%$ ) prefer a particular achievement goal, which functions as the most relevant one for them, at a particular point in time. Merchán-Clavellino et al., (2019) said that this disproportional role is connected with different activation systems in the social motivation's context. More specifically, the approach to social motivation is produced by Gray's behavioral activation system (BAS). The avoidance of social motivation is produced by Gray's behavioral inhibition system (BIS). People that have high BAS will be low in BIS, and vice versa. As a part of social motivation, this scheme can explain why, in this study, when facing opponents' anticipated joyfulness, the participants activate their performance-avoidance goals (Group 3). When opponents' distress is induced, the performance-approach goal is the only activated goal orientation (Group 2). Therefore, the stimulation using opponents' anticipated 
emotions could get through the BAS/BIS system and end with a single goal orientation.

Self-efficacy is not a static property and can be changed by stimulation, as found in this study. A situation, such as mastery experiences (i.e., previous successful behavioral performances), modeling (i.e., observation of successful behavioral performances), verbal persuasion, and physiological, affective states, time, and expected outcomes can change self-efficacy (Maddux and Rogers 1983; Schunk and Pajares 2009; Seifert and Sutton 2009).

Proponents' anticipated joyfulness and distress succeeded in boosting self-efficacy (Table 7) and opponents' anticipated joyfulness and distress failed to do so (Table 8). Proponents' anticipated distress is more prominent in that role. This result may be related to Ryan and Deci's (2017) social determination theory. As a theory about personality, when introjected into self-regulation, this theory states that people will internalize the expectations of significant other (such as family, close friend, and teacher) and build self-esteem and show themselves as socially responsible people by accepting and working for it. Consequently, as Chen et al., (2009) found in Taiwan, the demarcation line between personal and collective goals becomes blurred. This internalization should be more evident in Indonesia since, compared to their Chinese counterparts, Indonesian students are indoctrinated more strongly on collective-orientation regarding family values, security, conformity, achievement, motivation, performance-approach and performance-avoidance goals (Liem and Nie 2008).

Bosone and Martinez' (2017) found that anticipated loss is stronger than behavioral anticipated gain. Proponents' anticipated distress can be aligned with anticipated loss and proponents' anticipated joyfulness with anticipated gain. The first is stronger in its ability to increase the four elements of the achievement goals and for improving self-efficacy $(t=4.059$ vs. $t=3.475$, Table 7$)$ than the second. Finally, love for the proponents is a stronger motivator than hatred from the social environment. After all, "I will not let you down" (avoiding proponents' anticipated distress) is a more dominant statement of love than "I will make you happy" (creating proponents' anticipated joyfulness).

\section{Conclusion}

Proponents' joyfulness, anticipated as the response to individual success, increases the performance-approach and avoidance goals. Proponents' anticipated distress is described as a response to individual failures, and increases in the mastery-approach, mastery-avoidance, performance-approach, and performance-avoidance goals. Opponents' joyfulness, described as a schadenfreude emotion for individuals' failures, succeeded in increasing the performance-avoidance goal. Opponents' distress, described as the manifestation of social envy about individuals' successes, improved the performance-approach goal. Self-efficacy mediates the influence of the proponents' anticipated joyfulness on the performance-approach goal and the proponents' anticipated distress on the mastery-approach goal, partially. Love to the proponents is more influential than hatred from the social environment for influencing achievement motivation

\section{Limitation, Direction For Fur- ther Research}

The dependent variable in this study is still limited to the competence values to 
which achievement goals belong. Moral values, another instrumental value in Rokeach's value system (Farcane, Deliu, and Bureană 2019), remained untouched, with regard to the concept of concern. The question remains: Can other people's anticipated emotions (proponents vs. opponents) stimulate moral values-based motivation? Further research can investigate this.

In an experiment with a number of American bankers, Gino (2014) reported that when the participants were directed to think of their professional work, they tended to prioritize personal goals which showed indications of dishonesty. On the other hand, when reminded of their well-being and everyday life, they tend to act honestly. Anderman and Koenka (2017) also found that the pressure to show off extrinsic achievements motivates the students to cheat. Do other people's anticipated emotions work in this way? Further research can use the proponents' anticipated emotions (X1) and opponents' anticipated emotions (X2) as independent variables, the tendency to ignore morality as a dependent variable $(\mathrm{Y})$, and the working focus (professional vs. quality of life) as a moderating variable. The interesting questions are: What is the influence of $\mathrm{X} 1$ and $\mathrm{X} 2$ on Y? Is X1's influence on $\mathrm{Y}$ different from X2's? Does M moderate X1's and X2's influence on Y?

Abraham et al., (2020) study about moral emotions found that the employees' perceptions about their company's failure to fulfill its commitments, associated with its mutual promises (called a psychological contract breach or PCB), reduced the employees' perceived negativity of negative behavior and their negative self-evaluation. The higher the $\mathrm{PCB}$, the more tolerable the employees were to negative working behavior, and consequently, the less negative were their negative self-evaluations. This concept can be integrated into the present study in two ways. First, when a failure to achieve the set goals is viewed as an unexpected outcome that harms individuals' self-evaluations, the PCB's increase should lower the negativity of the failure and the related negative self-evaluations. Suppose mutual commitment is viewed as the proponents' failure to satisfy a mutual commitment (proponents' PCB). Will it reduce the effectiveness of the proponents' anticipated emotions (X1) to increase the achievement motivation (Y)? In other words, does the proponents' PBC moderate the influence of $\mathrm{X} 1$ on $\mathrm{Y}$ ?

Second, the need for achievement requires a healthy competitive environment to grow in. An unhealthy organizational environment can lead to individuals' unethical behavior. For example, Ramberg and Bodin (2019) reported that the lower a school's effectiveness was, conceptualized as poor commitment from the school's management, minimal cooperation from the teachers, and an inadequate school ethos, the greater was the students' cheating behavior. These unethical behaviors weaken the need for achievement (Adebayo 2010) and subsequently reduce the space for other people's anticipated emotions to function in. In this case, one can uses organizational's PBC (M) as a moderating variable by which the influence of the proponents' (X1) and opponents' (X2) anticipated emotions on achievement motivation (Y) may be weakened.

Recent studies reported that students in different disciplines have different mental health issues and proneness to experience mental disruptions. The students in science and engineering faculties have the best mental health, and those in humanities and art faculties have the worst (Lipson et al., 2016). The 
Gadjah Mada International Journal of Business - January-April, Vol. 23, No. 1, 2021

students in the social sciences field have the highest tendency to experience competition, anxiety, and depression, and again, students in sciences have the least (Posselt and Lipson 2016). The students in business disciplines are in a mediocre position. With these issues, further research can investigate whether the students in social sciences are the most sensitive, and students in the sciences are the least sensitive to other people's anticipated emotional stimulation.

\section{Contributions}

The study is hopefully beneficial scientifically and practically. The contributions to the scientific world can be traced to four considerations. First, others' anticipated emotions are a concept that has rarely materialized in the research until now, and this study is the pioneer for that issue. Therefore, its findings can be viewed as an original contribution.

Second, previous theories believed that the mastery-approach and performance-approach, known as the two actual achievement goals (Ames 1992; Nichols 1984), were activated by separate factors and situations. The mastery-approach's goal is induced by a belief that success is determined by a person's own efforts and strategy, and is less sensitive to the situation. The performance-approach's goal is viewed as depended on a person's talent and is less adaptive to a situation (Domenech-Betoret, Abellan-Rosello, and Gomez-Artiga 2017). This study found that, in addition to the previous theories, proponents' anticipated distress can function as the same determinant for the mastery-approach and performance-approach goals.
Third, the study about schadenfreude and social envy is commonly conducted from the perspective that the two behaviors are almost always viewed negatively (Brambilla and Riva 2017; van de Ven and Zeelenberg 2020). This study is among the pioneers in demonstrating how envy and schadenfreude function positively.

Fourth, this study seems to have two contradictory points concerning the question of whether the presence of goal orientations is inclusive (Elliot and Murayama 2008; Liem and Nie 2008) or exclusive (van Yperen 2006; Harackiewizc et al., 2002). However, this study bridges that gap, in which the same determinant (i.e., proponents' anticipated emotions) can induce both goal orientations to appear simultaneously. The single presence is evident along with the individuals' alertness of the opponents' anticipated joyfulness and distress. In short, the exclusivity of the inclusivity of the goals' orientation depends on the factor that stimulates them. This study is among the very few studies that assert this notion.

This study's findings can be useful for education practitioners or specialists, trainers, the management of training centers, consultants, families, and people who may be concerned with achievement motivation stimulation. They can increase the achievement motivation by reminding the subjects of the proponents' anticipated distress at their failure and joyfulness at their success. The subjects can also be stimulated to create a sense of being envied if they succeed or being a schadenfreude's target if they fail. The activation of the emotions depends on which achievement goal is the focus of attention. 


\section{References}

Abraham, J., Kurniadi, M.A., Andangsari, E.W., Ali, M.M., Manurung, R.H., and H.L.H. Warnar, 2020. Prediction of guilt and shame proneness based on disruption to psychological contract: A new light for corruption prevention. Heliyon, 6: e04275. https://doi.org/10.1016/j. heliyon.2020.e04275.

Adebayo, S.O., 2010. Correlation between academic cheating behavior and achievement motivation. Nature and Science of Sleep, 8(12): 130-134.

Ames, C.,1992. Classrooms: goals, structures, and student motivation. Journal of Educational Psychology, 84 (3), 261-271. https://doi.org/10.1037/0022-0663.84.3.261.

Alicke, M.D., and Sedikides, C., 2009. Self-enhancement and self-protection: What they are and what they do. European Journal of Social Psychology, 20(1): 1-48. https://doi. org/10.1080/10463280802613866.

Anderman, E.M., and A. C. Koenka, 2017. The relation between Academic motivation and cheating. Theory Into Practice, 56(2): 95-102. https://doi.org/10.1080/00405841.2017.1308172.

Bagozzi, R.P., D. Belanche, L.V. Casalo, and C. Flavian, 2016. The Role of anticipated emotions in purchase intentions. Psychology \& Marketing, 33(8): 629-645. https://doi.org/10.1002/ mar.20905.

Baron, A.M., and A. Wrzesniewski, 2010. I won't let you down ... or will I? Core self-evaluations, other-orientation, anticipated guilt and gratitude, and job performance. Journal of Applied Psychology, 95(1): 108-21. https://doi.org/10.1037/a0017974.

Baumgartner, H., R. Pieters, and R.P. Bagozzi, 2007. Future-oriented emotions: Conceptualization and behavioral effects. European Journal of Social Psychology, 38: 685-696. https://doi. org/10.1002/ejsp.467.

Belaza, B., K. Hoefman, J. Ryckebusch, A. Bramson, M. Van den Heuvel, and K. Schoors, 2017. Statistical physics of balance theory. Plos ONE, 12(8), e0183696. https://doi.org/10.1371/ journal.pone.0183696

Bozinovski, S., and L. Bozinovska, 2003. Anticipatory Behavior in Adaptive Learning Systems. In Butz et al. (Eds.), Anticipatory Behavior in Adaptive Learning Systems (pp. 1-10). Berlin, Germany: Springer.

Brambilla, M., and P. Riva, 2017. Predicting pleasure at others' misfortune: Morality trumps sociability and competence in driving deservingness and schadenfreude. Motivation and Emotion, 41, 243-253. https://doi.org/10.1007/s11031-016-9594-2.

Bosone, L., and F. Martinez, 2017. When, how and why is loss-framing more effective than gainand non-gain-framing in the promotion of detection behaviors? International Review of Social Psychology, 30(1), 184-192, 2017. https://doi.org/10.5334/irsp.15.

Buonomo, I., C. Fiorilli, and P. Benevene, 2019. The impact of emotions and hedonic balance on Teachers' self-efficacy: Testing the bouncing back effect of positive emotions. Frontiers in Psychology, 10:1670. https://doi.org/10.3389/fpsyg.2019.01670.

Chasiotis, A., O. Wedderhoff, T. Rosman, and A.K. Mayer, 2019. The role of approach and avoidance motivation and emotion regulation in coping via health information seeking. Current Psychology: A Journal for Diverse Perspectives on Diverse Psychological Issues. Advance online publication. https://doi.org/10.1007/s12144-019-00488-3. 
Gadjah Mada International Journal of Business - January-April, Vol. 23, No. 1, 2021

Chen, S-. W., H.- H. Wang, C. -F. Wei, B.- J. Fwu, and K.- K. Hwang, 2009. Taiwanese students' self-attribution for two types of achievement goals. The Journal of Social Psychology, 149(2), 179-193. https://doi.org/10.3200/SOCP.149.2.179-194.

Domenech-Betoret, F., L. Abellan-Rosello, and A. Gomez-Artiga, 2017. Self-efficacy, satisfaction, and academic achievement: The mediator role of students' expectancy-value beliefs. Frontiers in Psychology, 8 (1193). https://doi.org/10.3389/fpsyg.2017.01193.

Dompnier, B., C. Darnon, and F. Butera, 2013. When performance $\square$ approach goals predict academic achievement and when they do not: A social value approach. British Journal of Social Psychology, 52(3), 587-596. https://doi.org/10.1111/bjso.12025.

Elliot, A. J., and H.A. McGregor, 2001. A $2 \times 2$ achievement goal framework. Journal of Personality and Social Psychology, 80, 501-519. https://doi.org/10.1037//0022-3514.80.3.501.

Elliot, A.J., and J.M. and Harackiewicz, 1991. Approach and avoidance achievement goals and intrinsic motivation: a mediational analysis. Journal of Personality and Social Psychology, 70, 461475. https://doi.org/10.1037/0022-3514.70.3.461.

Elliot, A.J., and K. Murayama, 2008. On the measurement of achievement goals: Critique, illustration, and application. Journal of Educational Psychology, 100 (3), 613-628. https://doi. org/10.1037/0022-0663.100.3.613.

Eskritt, M., J. Doucette, and L. Robitaille, 2014. Does future-oriented thinking predict adolescent decision making? The Journal of Genetic Psychology: Research and Theory on Human Development, 175 (2), 163-179. https:// doi.org/10.1080/00221325.2013.875886.

Farcane, N., D. Deliu, and E. Bureana, 2019. A Corporate Case Study: The Application of Rokeach's Value System to Corporate Social Responsibility (CSR). Sustainability, 2019, 11, 6612. https:/ / doi.org/10.3390/su11236612.

Fiori, M., and A.K. Vesely-Maillefer, 2018. Emotional intelligence as an ability: Theory, challenges, and new directions. In Keefer K., J. Parker, D. Saklofske, (Eds). Emotional Intelligence in Education. Cham, CH: Springer. https://doi.org/10.1007/978-3-319-90633-1_2.

Gegenfurtner, A., and G. Hagenauer, 2013. Achievement goals and achievement goal orientations in education. International Journal of Educational Research, 61(1), 1-4. https://doi.org/10.1016/j. ijer.2013.08.001.

Gino, F., 2014, December 30. Banking culture encourages dishonesty. Scientific American. https:// www.scientificamerican.com/article/banking-culture-encourages-dishonesty/.

Goodman, J. K., and S. Lim, 2018. When consumers prefer to give material gifts instead of experiences: The role of social distance. Journal of Consumer Research, 45, 365-382. https://doi. org/10.1093/jcr/ucy010.

Grant, A.M., and A. Wrzeniewski, 2010. I won't let you down ... or will I? Core self-evaluations, other-orientation, anticipated guilt and gratitude, and job performance. Journal of Applied Psychology, 95(1):108-21, https://doi.org/10.1037/a0017974.

Hair, J.F., W.C. Black, B.J. Babin, and R.E. Anderson, 2016. Multivariate Data Analysis. Seventh Edition. Edinburg, UK: Pearson Education Limited.

Harackiewicz, J.M., K.E. Barron, P.R. Pintrich, A.J. Eliot, and T.M. Thrash, 2002. Revision of achievement goal theory: Necessary and illuminating. Journal of Educational Psychology, 2002, 94 (3), 638-64. https://doi.org/10.1037//0022-0663.94.3.638.

Hayes, A.F., 2020. Process (Version 3.5) [Application software]. Retrieved August 16, 2020, from http:/ / 
www.processmacro.org/download.html.

Huang, C, 2016. Achievement goals and self-efficacy: A meta-analysis. Educational Research Review, 19, 119-137. https:// doi.org/10.1016/j.edurev.2016.07.002.

Israelashvili, J., D. Sauter, and A.H. Fischer, 2019. How well can we assess our ability to understand others' feelings? Beliefs about taking others' perspectives and actual understanding of others' emotions. Frontiers in Psychology. https://doi.org/10.3389/fpsyg.2019.02475.

Kenny, D.A., 2018. Mediation. Retrieved April 21, 2019, from http://davidakenny.net/cm/mediate. htm.

Kim, S. C., Y.S. Park, B. S.-W. Ho, and I. Wu, 2017. Family conflict, Asian cultural values, perceived parental control, and affectionate care among Asian American college students. Journal of Asia Pacific Counseling, 7(2): 123-140. https://doi.org/10.18401/2017.7.2.2.

Ladd, G.W., 2017. School bullying linked to lower academic achievement, research finds. American Psychology Association. Retrieved April 23, 2019, from https://www.apa.org/news/press/ releases/2017/01/school-bullying.aspx.

Leahy, R.L. (2020). Cognitive-behavioral therapy for envy. Cognitive Therapy and Research. https://doi. org/10.1007/s10608-020-10135-y.

Liem, A. D., and Y. Nie, 2008. Values, achievement goals, and individual-oriented and social-oriented achievement motivations among Chinese and Indonesian secondary school students. International Journal of Psychology: Journal International De Psychologie, 43(5): 898-903. https://doi. org/10.1080/00207590701838097.

Lipson, S. K., S. Zhou, B. Wagner III, K. Beck, and D. Eisenberg, 2016. Major differences: Variations in undergraduate and graduate student mental health and treatment utilization across academic disciplines. Journal of College Student Psychotherapy, 30(1), 23-41. https://doi.org/10.1 080/87568225.2016.1105657.

Maddux, J., and R. Rogers,1983. Protection motivation and self-efficacy: A revised theory of fear appeals and attitude change. Journal of Experimental Social Psychology, 19, 469-479. https://doi. org/10.1016/0022-1031(83)90023-9.

Malhotra, N. K., 2020. Marketing Research: An Applied Orientation. Seventh Edition. Upper Saddle River, NJ: Prentice-Hall, Inc.

Manstead, A.S.R., 2018. The psychology of social class: How socioeconomic status impacts thought, feelings, and behavior. British Journal of Social Psychology, 57, 267-291. https://doi.org/10.1111/ bjso.12251.

MacKinnon, D. P., C.M. Lockwood, and J. Williams, 2004. Confidence limits for the indirect effect: Distribution of the product and resampling methods. Multivariate Behavioral Research, 39(1), 99-128. https://doi.org/10.1207/s15327906mbr3901_4.

Mellers, B.A., and A.P. McGraw, 2001. Anticipated emotions as guides to choice. Current Direction in Psychological Science, 10 (6), 210-214. https://doi.org/10.1111\%2F1467-8721.00151.

Merchán-Clavellino, A., J.R. Alameda-Bailén, A. Z. García, and R. Guil, 2019. Mediating effect of trait emotional intelligence between the behavioral activation system (BAS)/Behavioral Inhibition System (BIS) and Positive and Negative Affect. Frontiers on Psychology, 10: 424. https:// doi.org/10.3389/fpsyg.2019.00424.

Miočević, M., O. Gonzalez, M.J. Valente, and D.P. MacKinnon, 2018. A tutorial in Bayesian potential outcomes mediation analysis. Structural Equation Modeling, 25(1), 121-136. https://doi.org/1 
Gadjah Mada International Journal of Business - January-April, Vol. 23, No. 1, 2021

0.1080/10705511.2017.1342541.

Moussard, M., J.E. Kammer, P.P. Analytis, and H. Neth, 2013. Social influence and the collective dynamics of opinion formation. PLoS ONE, 8(11): e78433. https://doi.org/10.1371/journal. pone.0078433.

Munroe, P.T., 2019. Cognitive balance theory. In G. Ritzer and C. Rojek (Eds.). The Blackwell Encyclopedia of Sociology (pp. 1-3). Hoboken, NJ: John Wiley \& Sons, Ltd.

Murayama, K., A.J. Elliot, and S. Yamagata, 2011. Separation of performance-approach and performance-avoidance achievement goals: A broader analysis. Journal of Educational Psychology, 103(1), 238-256. https://doi.org/10.1037/a0021948.

Nicholls, J.G.,1984. Achievement motivation: Conceptions of ability, subjective experience, task choice, and performance. Psychological Review, 91(3), 328-346. https://doi.org/10.1037/0033295X.91.3.328.

Passafaro, P., S. Livi, and A. Kosic, 2019. Local norms and the theory of planned behavior: Understanding the effects of spatial proximity on recycling intentions and self-reported behavior. Frontiers in Psychology, 10, 744. https://doi.org/10.3389/fpsyg.2019.00744.

Pintrich, P. R., D. A. F., Smith, T. Garcia, and W. J. McKeachie, 1991. A Manual for the Use of the Motivated Strategies for Learning Questionnaire (MSLQ). Sponsored by National Center for Research to Improve Postsecondary Teaching and Learning, Ann Arbor, MI. Retrieved March 12, 2019, from http:/ / files.eric.ed.gov/fulltext/ED338122.pdf.

Posselt, J. R., and S.K. Lipson, 2016. Competition, Anxiety, and Depression in the College Classroom: Variations by Student Identity and Field Study. Journal of Colege Student Development, 57(8), 973-989. https://doi.org/10.1353/csd.2016.0094.

Preacher, K. J., and A.F. Hayes, 2004. SPSS and SAS procedures for estimating indirect effects in simple mediation models. Behavior Research Methods, Instruments \& Computers, 36(4), 717 731. https:// doi.org/10.3758/BF03206553.

Putarek, V., and N. Pavlin-Bernardić, 2020. The role of self-efficacy for self-regulated learning, achievement goals, and engagement in academic cheating. European Journal of Psychology of Education, 35. https://doi.org/10.1007/s10212-019-00443-7.

Ratsameemonthon, L., 2015. Achievement goal questionnaire-revised for Thai college students and Asian context. Electronic Journal of Research in Educational Psychology, 13 (2), 369-386. https:// doi.org/10.14204/ejrep.36.14078.

Reb, J., and T. Connoly, 2007. Possession, feelings of ownership, and the endowment effect. (2007). Judgment and Decision Making. 2, (2), 107-114. Retrieved from https://ink.library.smu. edu.sg/lkcsb_research/2664/.

Ramberg, J., and B. Modin, 2019. School effectiveness and student cheating: Do students' grades and moral standards matter for this relationship?. Social Psychology of Education, 22: 517538. https://doi.org/10.1007/s11218-019-09486-6.

Rosas, J.S., 2015. Validation of the achievement goal questionnaire - Revised in Argentinean university students (A-AGQ-R). International Journal of Psychology Research, 8(1), 10-23. https://doi. org/10.21500/20112084.641.

Ryan, R. M., and E.L. Deci, 2017. Self-Determination Theory: Basic Psychological Needs in Motivation, Development, and Wellness. New York, NY: The Guilford Press. https://doi. org/10.1521/978.14625/28806. 
Schneider, C. R., L. Zaval, E.U. Weber, and E.M. Markowitz, 2017. The influence of anticipated pride and guilt on pro-environmental decision making. PLOS ONE, 12(11), Article e0188781. https://doi.org/10.1371/journal.pone.0188781.

Schunk, D. H., and F. Pajares, 2009. Self-efficacy theory. In K. R. Wenzel, and A. Wigfield (Eds.), Educational Psychology Handbook Series. Handbook of Motivation at School (pp. 35-53). New York, NY: Routledge/Taylor and Francis Group.

Seifert, K., and R. Sutton, 2009. Educational Psychology. Second Edition. Retrieved March 22, 2019, from http://home.cc.umanitoba.ca/ seifert/EdPsy2009.pdf.

Simamora, B., 2016. Achievement as gift and prestige: Formulating anticipated emotions of others as new determinant of consumers' motivation. ASEAN Marketing Journal, 8 (1), 2953. https://doi.org/10.21002/amj.v8i1.9258.

Sun, W., 2019. Toward a theory of ethical consumer intention formation: Re-extending the theory of planned behavior. AMS Review. https://doi.org/10.1007/s13162-019-00156-6.

Tamir, M., and Y.E. Bigman, 2018. Expectations influence how emotions shape behavior. Emotion, 18(1): 15-25. https://doi.org/10.1037/emo0000351.

Thøgersen, J., 2006. Norms for environmentally responsible behaviour: An extended taxonomy. Journal of EnvironmentalPsychology, 26(4):247-261. http://dx.doi.org/10.1016/j.jenvp.2006.09.004.

Van der Schalk, J., T. Kuppens, M. Bruder, and A. S. R. Manstead, 2015. The social power of regret: The effect of social appraisal and anticipated emotions on fair and unfair allocations in resource dilemmas. Journal of Experimental Psychology. General, 144(1): 151-157. https://doi. org/10.1037/xge0000036.

Van de Ven, N., and M. Zeelenberg, 2020. Envy and social comparison. In J. Suls, R. Collins, \& L. Wheeler (Eds.), Social Comparison in Judgment and Behavior (pp. 223-247). Oxford University. https://doi.org/10.1093/oso/9780190629113.003.0009.

Van Yperen, N.W., 2006. A novel approach to assessing achievement goals in the context of the $2 \times 2$ framework: Identifying distinct profiles of individuals with different dominant achievement goals. Personality and Social Psychology Bulletin, 32 (11), 1432 - 1445, https://doi. org/10.1177/0146167206292093.

Volz, K. G., and R. Hertwig, 2016. Emotions and decisions: Beyond conceptual vagueness and the rationality muddle. Perspectives on Psychological Science, 11(1), 101-116. https://doi. org/10.1177/1745691615619608.

Wang, S., S.O. Lilienfeld, and R. Philippe, 2019. Schadenfreude deconstructed and reconstructed: A tripartite motivational model. New Ideas in Psychology. 52: 1-11. https:// doi.org/10.1016/j. newideapsych.2018.09.002.

Westcott, R., K. Ronan, H. Bambrick, and M. Taylor, 2017. Expanding protection motivation theory: investigating an application to animal owners and emergency responders in bushfire emergencies. BMC psychology, 5(1), 13. https://doi.org/10.1186/s40359-017-0182-3.

Zeelenberg, M., 2018. Anticipated regret: A prospective emotion about the future past. In G. Oettingen, A. T. Sevincer, and P. Gollwitzer (Eds.), The Psychology of Thinking about the Future (pp. 276-295). New York, NY: The Guilford Press.

Zhao, X., J.G. Lynch, Jr., and Q. Chen, 2010. Reconsidering Baron and Kenny: Myths and truths about mediation analysis. Journal of Consumer Research, 37(2), 197-206. https://doi. org/10.1086/651257. 